\title{
Traditional knowledge about plant, animal, and mineral-based remedies to treat cattle, pigs, horses, and other domestic animals in the Mediterranean island of Sardinia
}

\author{
Simonetta Bullitta ${ }^{1 *}$ (D), Giovanni Antonio Re ${ }^{1}$, Maria Domenica Iole Manunta ${ }^{1,2}$ and Giovanna Piluzza ${ }^{1}$
}

\begin{abstract}
Background: Mediterranean farmers traditionally utilized plants, animals, and minerals sourced locally to treat their animals. Research is needed to understand at what extent such knowledge of domestic animal care still survives and to document such traditions for further developments.

Methods: We carried out our field study to recover ancient ethno-veterinary practices by means of questionnaires and interviews to farmers in rural areas of the Mediterranean island of Sardinia (Italy). Quantitative indices were used to evaluate the distribution and diversity of the acquired information.

Results: We report here 98 sources (42 plant taxa, 14 animal-based substances, 15 minerals, and 27 other materials of various origin) emerged from the survey for the care of 41 ailments of cattle, pigs, and horses. Ethno-veterinary treatments, detailed in their formulations and applications, were used against ecto- and endo-parasites, gastrointestinal diseases, heart diseases, viral and bacterial diseases, wounds, sprains, and bruises.

Conclusion: Our survey can be useful to implement the use of phyto-therapeutics and other remedies of non-herbal origin for diseased animals, and, as elderly farmers held most of the knowledge, it can contribute to the conservation of Mediterranean ethno-veterinary knowledge.
\end{abstract}

Keywords: Mediterranean ethno-veterinary, Plant remedies, Traditional therapeutics, Zoo-therapy, Livestock, Poultry, Pets

\section{Background}

The knowledge and practices related to the use of medicinal plants for the treatment of human and animal diseases has been handed down from generation to generation in different cultures worldwide. In recent years, the traditional uses of numerous medicinal plants have been corroborated by scientific evidence [1]. The use of biological resources for medicinal purposes, however, is not restricted to human disease treatment, being also widely employed for treating diseases of livestock [2, 3]. These uses fall within the remit of ethno-veterinary medicine (EVM). The ethno-veterinary pharmacopoeia often contains ingredients sourced from various locations within

\footnotetext{
*Correspondence: simonettamaria.bullitta@cnr.it

${ }^{1}$ Istituto per il Sistema Produzione Animale in Ambiente Mediterraneo CNR-ISPAAM, Traversa La Crucca 3, località Baldinca, 07100 Sassari, Italy Full list of author information is available at the end of the article
}

the environment and may include plants, animals, and minerals [4].

In former times, the knowledge of medicinal plants was passed down orally from generation to generation; however, in modern Western societies of Europe, traditional knowledge is in danger of disappearing [5]. Ethno-veterinary surveys, on the preparation and utilization of herbal remedies have been conducted in Palestine, Latin America, Iran, Spain, Italy, Algeria, Morocco, Southern Italy, Brazil, Pakistan, India, and Polish-Lithuanian-Belarusian borderland [6-18].

The European Council Regulations on Organic Farming (nos. 834/2007 and 889/2008) [19] promote veterinary complementary medicine, i.e. phyto-therapeutic products, for the treatment of livestock diseases. Chemically synthesized allopathic veterinary medicines including antibiotics should only be used under the strict rules of Council 
Regulation (EC) no. 834/2007. There is an increasing demand for high-quality animal food products with no or limited use of pharmaceuticals produced either chemically or biotechnologically [6]. Ethno-veterinary data collected in the Mediterranean region can offer an extraordinary background for conducting studies aimed at implementing phytotherapy in animal health care and the use of plant-derived nutraceuticals, with the aim of improving the quality of animal-derived food products [20]. Many authors have argued that animals and/or their derivatives for medicinal use is a global phenomenon, dating back to prehistoric times and coevolving with human societies $[21,22]$. In this respect, invertebrates and cognate products have been used worldwide to cure and/or prevent different human diseases [23-26]. The great interest around this group of animals, in particular insects, has grown due to their ability to synthesize a large number of chemical compounds [27]. Animals and products derived from their organs have constituted part of the inventory of medicinal substances used in different cultures since ancient times [24]. Despite its prevalence in traditional medical practices worldwide, research on medicinal animals, in comparison with medicinal plant research, has been often neglected [21, 28]; major emphasis have been put on medicinal plants because far more many species have been employed compared to medicinal animals. In addition, plants are somehow easier to collect, store, and trade. The importance of zoo-therapy in various socio-cultural environments around the world has been investigated [24]. A review on the ethno-veterinary use of invertebrates has revealed that humans have always considered this animal group as a source of surprising and extensive therapeutic properties [29].

Even though plants are at the core of ethno-veterinary medicine, other practices were also used, such as the use of drugs of animal origin and cauterization medicine.

The recovery of traditional plant knowledge (TPK) linked to their medicinal use is one of the most urgent and immediate issues needing attention, as confirmed by international researches. The preservation of popular traditions can contribute not only to identify new uses of plant species and to maintain ethno-biodiversity, but eventually to discover also novel biologically active compounds to treat diseases [30].

We have previously described ethno-veterinary treatments for small ruminants [13], here we point out the use of plants and their formulations for administration to cattle, horses, pigs, and dogs. In addition to plants, our study also revealed the use of further remedies of different nature and origin. Sardinian farmers utilized animals, minerals, and combinations of different materials to formulate remedies for their animals for prophylactic or therapeutic purposes.

\section{The study area}

Cattle and pigs have been recorded in Sardinia since the Neolithic time; consequently, traditions of animal care date back to millennia. Cattle played an important role as working animals since the Nuragic period, during the Bronze Age, and this until the first part of the twentieth century, when draught animals were replaced by engines [31]. Horses were first introduced in Sardinia from Greece between the sixth and the fifth century B.C. [32]. The Roman Empire kept a breeding ground in the island for horses to be used in war and by gladiators; Saracen domination improved the Sardinian breeds crossing them with Arabian and Bedouin strains [33], and further breeding was developed towards the end of 1400 under the dominion of the Aragon Crown [33]. An intertwining of people, traditions, and knowledge about the care of domestic animals over the centuries makes the ethno-veterinary traditions of Sardinia peculiar and somehow unique. It is important to understand what is the current ethno-veterinary knowledge and at what extent plant, animal, and mineral substances are still in use in the traditional ethno-veterinary practices of Mediterranean areas.

Our aim was to perform a survey of Sardinian ethno-veterinary traditions not only those related to the use of plant species but also those involving other substances of animal or mineral origin and their combinations, in order to implement the studies on Mediterranean ethno-veterinary practices that are still poorly investigated. Our aim was also to understand which remedies were still in use and to document ethno-veterinary traditions to preserve them and prevent their unavoidable loss due to the oral way of transmission.

\section{Methods}

\section{Ethnobotanical data collection}

The investigation on traditional ethno-veterinary remedies was performed visiting Sardinian farmers and interviewing them individually at their farms. A questionnaire with open and closed questions was prepared according to Viegi et al. [34], with some modifications, as we aimed to recover all the ancient remedies of ethno-veterinary practices and not only those involving the use of plants. Our interviewees were asked to answer questions related to the type of illnesses and the animal species treated, to the preparation and the administration of the remedy, the frequency (current and past) of its use, and whether the same remedy was also employed for other purposes. The original forms filled for each remedy during the interviews are stored at CNR-ISPAAM.

We interviewed 60 people, 50 men and 10 women, aged between 46 and 96 years old, being most of the participants between 61 and 80 years old (Fig. 1) with an average age \pm standard deviation of $71.8 \pm 13.7$. All 


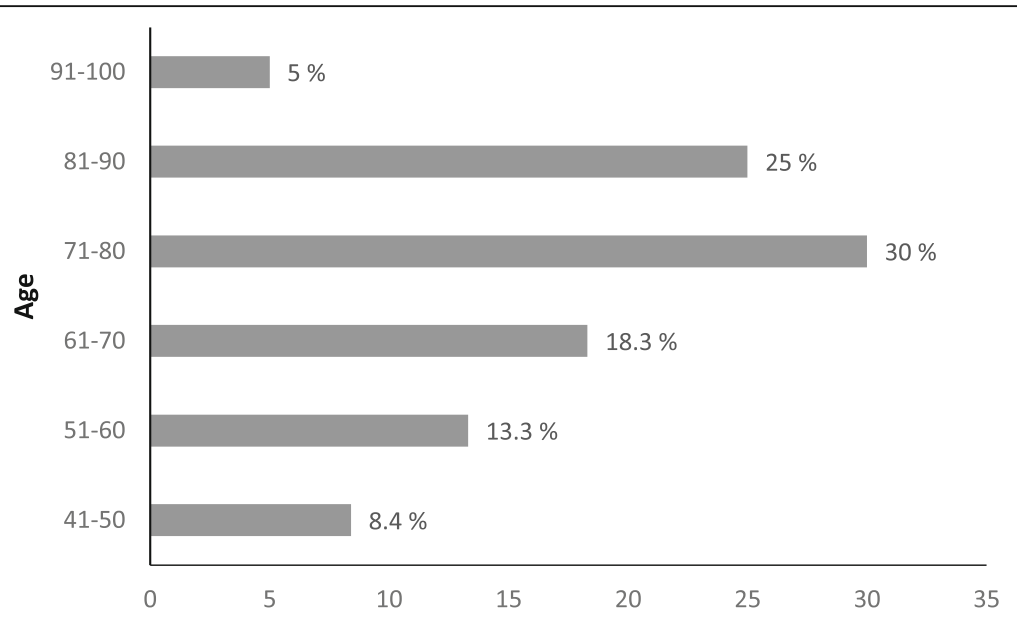

Fig. 1 Percentage distribution of the interviewees into age groups

people were farmers and raised their animals in the Sardinian rural districts of Anglona, Barbagia, Campidano, Meilogu, Monte Acuto, Gallura, Goceano, Nurra, and Sassarese (Fig. 2). We paid particular attention on elderly people and to farms devoted to extensive animal breeding. We describe here remedies adopted for cattle, horses, pigs, poultry, dogs, and cats. According to the interviewees, most of the remedies were actively used between 1925 and 1985; however, considering that almost all stated to have learnt about the remedies from their parents or elderly relatives, it is likely that the remedies originated in earlier times.
Herbarium voucher specimens were collected during the interviews and are stored at CNR-ISPAAM in Sassari. The identity of plants was confirmed by classification according to Pignatti [35] and Conti et al. [33, 34, 36]; familial nomenclature follows the Angiosperm Phylogeny Group (APG IV) [37].

\section{Data analysis}

Three indices were applied: the Cultural Importance index (CI), the Relative Frequency of Citation (RFC), and the Relative Importance Index (RI):

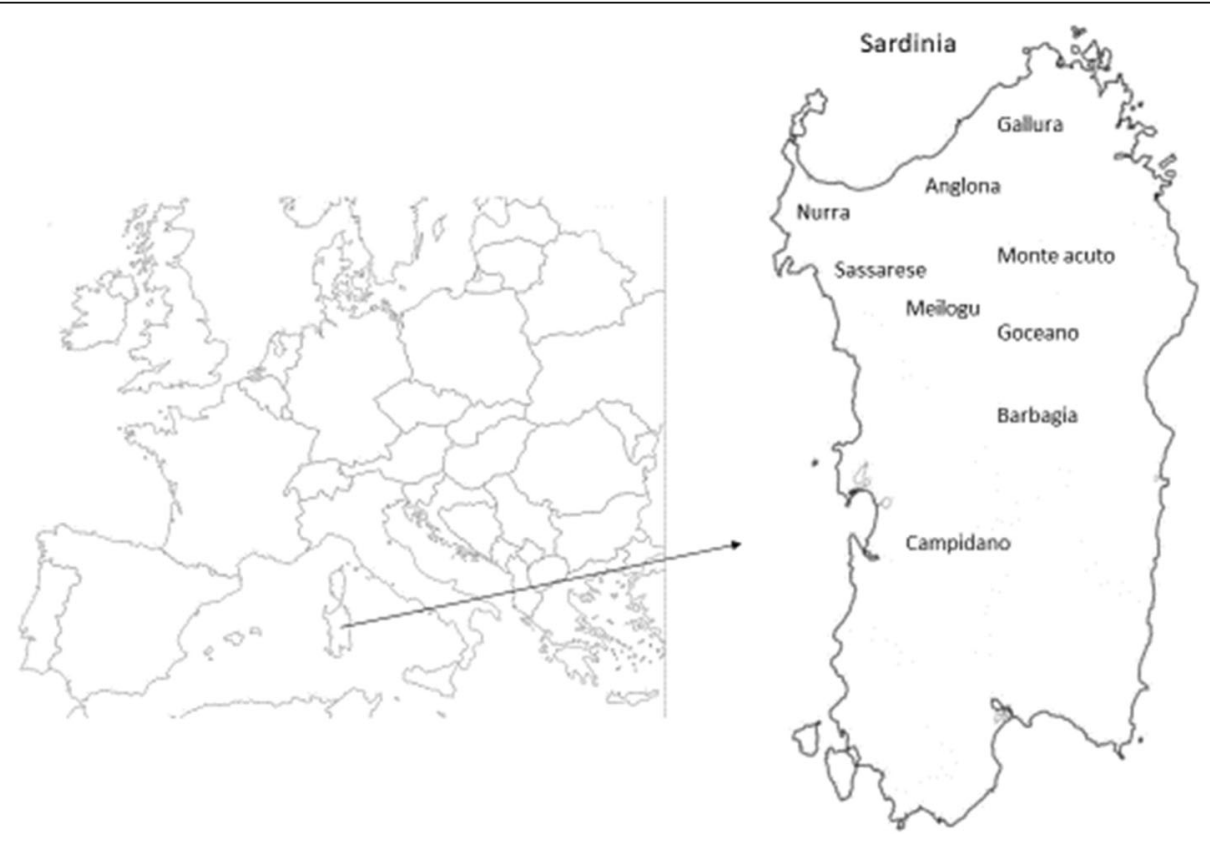

Fig. 2 Map of Sardinia with the study areas 
1) The Cultural Importance index (CI), takes into account the spread of use and the diversity of uses of each plant species, according to Tardio and Pardo-de-Santayana [38], and represents the sum of the proportion of interviewees that mention each species use,

$$
\mathrm{CI}_{s}=\sum_{u=u_{1}}^{u_{N C}} \sum_{i=i_{1}}^{i_{N}} \mathrm{UR}_{u i} / N
$$

it represents the sum of all the use reports (UR) for the species divided by the number of interviewees $(N)$.

2) The Relative Frequency of Citation (RFC) was calculated as follows: the number of interviewees indicating the use of the species, also defined as frequency of citation $(\mathrm{FC})$, divided by the total number of the interviewees $(N)$,

$$
\mathrm{RFC}_{s}=\frac{\mathrm{FC}_{s}}{N}=\frac{\sum_{i=i_{1}}^{i_{N}} \mathrm{UR}_{i}}{N}
$$

where UR is the sum of the use report of the species regardless the category use of the species.

3) The Relative Importance Index (RI) according to Pardo-de-Santayana [39] takes into account the use categories.

$$
\mathrm{RI}_{s}=\frac{\mathrm{RFC}_{s(\max )}+\mathrm{RNU}_{s(\max )}}{2}
$$

where $\mathrm{RFC}_{s(\max )}$ is the relative frequency of citation over the maximum number of citation, obtained by dividing FCs by the maximum value in all the species of the survey. $\mathrm{RNU}_{s(\max )}$ is the relative number of use categories over the maximum, obtained by dividing the number of uses of the species by the maximum value in all the species in the survey. The use categories were (a) ecto- and endo-parasite diseases, (b) gastrointestinal diseases and heart diseases, (c) viral and bacterial diseases, and (d) wounds, sprains, and bruises.

The survey was carried out taking into account the protection of biodiversity and the rights of local people according to the principles stated by [40, 41], in agreement with the principles of the International Society of Ethnobiology Code of Ethics (http://ethnobiology.net/ code-of-ethics/).

Some of the ethno-veterinary practices here reported do not comply with the Italian national legislation for domestic animal welfare (D.L.146/2001) or European community regulations concerning the protection of animals kept for farming purposes (Council directive 98/ $58 / \mathrm{EC})$. They are just reported and not endorsed by authors and although dismissed are mentioned for the sake of completeness of the survey.

\section{Results}

\section{Quantitative analysis}

We found that in the Sardinian traditional health care for domestic animals, the percentage of ethno-botanical remedies was $51.4 \%$ while zoo-therapeutics accounted for $14.4 \%$, physical acts and manipulation therapies were $7 \%$, and the mineral and chemical treatments were $27.2 \%$. (Fig. 3). No magic rituals were mentioned by our interviewees. The highest number of remedies (90) was reported by the participants aged between 71 and 80 years (Fig. 4).

The identified traditional ethno-veterinary remedies were used to treat cattle, horses, pigs, dogs, cats, and hens against ecto- and endo-parasites, gastrointestinal diseases, heart diseases, viral and bacterial diseases, wounds, sprains, and bruises. Ninety-eight sources were documented in this survey, including: 42 plant taxa, 14

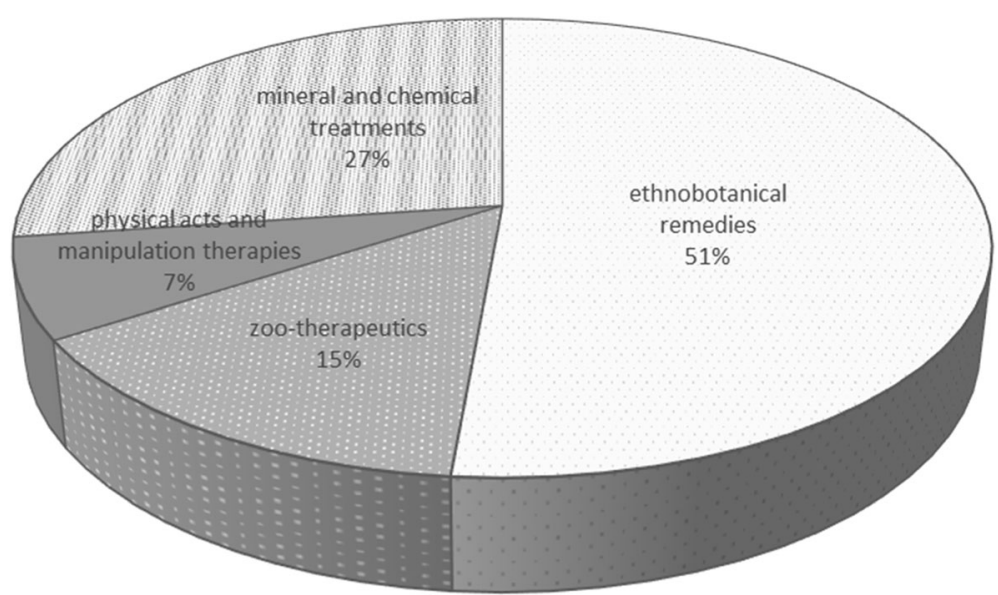

Fig. 3 Percentage distribution of plant-, animal-, and mineral-based remedies 


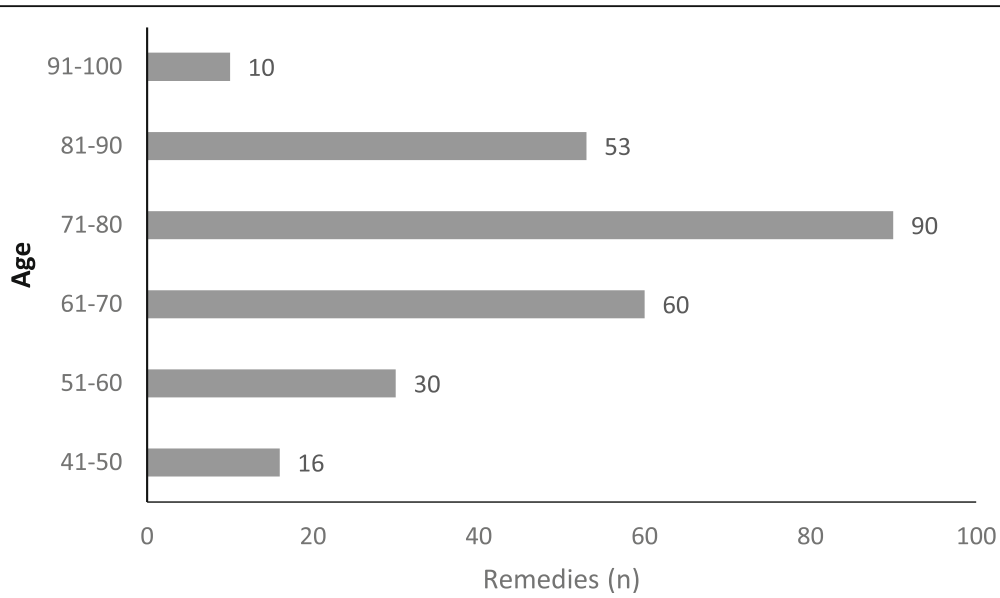

Fig. 4 Number of recorded remedies according to the age group of the interviewees

animal derivatives, 15 minerals, and 27 other materials of various origins. The herbal remedies included 30 spontaneous plant species, quite widespread in the Sardinian pasturelands, 11 cultivated species (onion, garlic, oat, parsley, tobacco, barley, wheat, broad beans, lineseed, olive, vine), and 1 ornamental (camellia). The plants mentioned belonged to 29 botanic families. The most represented were Poaceae with five species, Apiaceae with four species, followed by Leguminosae, Malvaceae, Urticaceae, Asteraceae, and Fagaceae with two species each. Plant-derived products such as olive oil, vinegar, beer, and cork were also used alone or in combination with other substances to prepare remedies. Plant species and their ethnobotanical indices are listed in Table 1. The ranking according to each index (Table 1) shows that the species Olea europaea L., Vitis vinifera L., Malva sylvestris L., Hordeum vulgare L., Parietaria officinalis L., Pistacia lentiscus L., Matricaria chamomilla L., and Triticum durum Desf. were in the first eight positions due to their higher indices. The species Vitis vinifera and Olea europaea which ranked in the first two positions for CI, RI, RFC were among the most cited ( 26 and 22 interviewees, respectively) for the treatments of 6 and 8 ailments. The local importance of each species calculated by using the Relative Frequency of Citation (RFC) showed that Vitis vinifera (RFC 0.43), Olea europaea (RFC 0.37), and Malva sylvestris (RFC 0.33) represent the core of the cultural ethnobotanical heritage in the investigated areas (Table 1). The same table shows the RI index of plant species. Vitis vinifera (RI 1) was employed in all the four use categories. Olea europaea (RI 0.80), Malva sylvestris (RI 0.76), Parietaria officinalis (RI 0.57), Pistacia lentiscus (RI 0.55), and Triticum durum (RI 0.51) were employed in three of the four use categories. They showed higher RI values compared to the other plant species with RI values ranging from 0.38 to 0.14 and employed for two or one use categories.

The non-herbal remedies (Table 2) involved the use of substances such as lard, salt, ashes, ozzu casu (fat obtained by boiling the cream of milk with flour), copper sulphate, ozzu brujadu (reused motor oil), ozzu porchinu (fat from lard), and ozzu seu (dried peritoneum of sheep). According to the RFC index (Table 3), the most locally important among the sources different from plants were lard (RFC 0.35), salt (RFC 0.23), and ashes (RFC 0.22). As shown on Table 2, salt was cited by 14 interviewees for treating seven diseases in cattle and horses; the use of ashes in nine different remedies was indicated by 13 interviewees for the treatment of six diseases occurring in cattle, horses, and pigs. Among the animal-derived substances, the lard usage was cited by 21 interviewees as component of 11 different remedies to treat four diseases affecting cattle and horses. The highest values for the CI index of sources different from plants (Table 3) were found for lard (CI 0.32), salt (CI 0.20), copper sulphate (CI 0.19), ozzu casu (CI 0.19 ), and ashes (CI 0.16). According to the RI of such sources, lard (RI 0.60), salt (RI 0.53) and ozzu casu (RI 0.48 ), employed in three of the four use categories, showed higher values, compared to other 11 sources which showed RI ranging from 0.44 to 0.27 (clay, ashes, copper sulphate, ozzu brujadu, cuttlefish bone, ozzu seu, sugar, knife, ozzu porchinu, seawater, cow's milk) and which were employed in only two of the four use categories. Lard and salt were used for ailments included in the use categories of gastrointestinal diseases, viral and bacterial diseases, and wounds, sprains, and bruises, while ozzu casu was reported for ailments in the use categories of ecto- and endo-parasite diseases, viral and bacterial diseases, and wounds, sprains, and bruises. 
Table 1 Quantitative indices of plant species: Cl (cultural importance); RI (relative importance); RFC (relative frequency of citation)

\begin{tabular}{|c|c|c|c|c|c|c|c|c|}
\hline \multirow{2}{*}{$\begin{array}{l}\text { Voucher } \\
\text { specimen }\end{array}$} & \multirow[t]{2}{*}{ Species (Family) ${ }^{a}$} & \multirow[t]{2}{*}{ Local names } & \multicolumn{3}{|c|}{ Indices } & \multicolumn{3}{|c|}{ Ranking } \\
\hline & & & $\mathrm{Cl}$ & $\mathrm{Rl}$ & RFC & $\mathrm{Cl}$ & $\mathrm{Rl}$ & RFC \\
\hline GPE13 & Olea europaea L. (Oleaceae) & Olìa & 0.35 & 0.80 & 0.37 & 1 & 2 & 2 \\
\hline GPE36 & Vitis vinifera L. (Vitaceae) & Bide & 0.35 & 1 & 0.43 & 2 & 1 & 1 \\
\hline GPE11 & Malva sylvestris L. subsp. sylvestris (Malvaceae) & Pramuzza & 0.25 & 0.76 & 0.33 & 3 & 3 & 3 \\
\hline GPE30 & Hordeum vulgare L. (Poaceae)) & Ozu & 0.12 & 0.38 & 0.12 & 4 & 7 & 6 \\
\hline GPE16 & Parietaria officinalis L. (Urticaceae) & Pigulosa & 0.10 & 0.57 & 0.17 & 5 & 4 & 4 \\
\hline GPE18 & Pistacia lentiscus L. (Anacardiaceae) & Chessa & 0.10 & 0.55 & 0.15 & 6 & 5 & 5 \\
\hline GPE12 & Matricaria chamomilla L. (Asteraceae) & Caboniglia & 0.08 & 0.35 & 0.08 & 7 & 8 & 9 \\
\hline GPE38 & Triticum durum Desf. (Poaceae) & Trigu & 0.08 & 0.51 & 0.12 & 8 & 6 & 7 \\
\hline GPE01 & Allium cepa L. (Amaryllidaceae) & Chibudda & 0.05 & 0.24 & 0.10 & 9 & 14 & 8 \\
\hline GPE33 & Quercus pubescens Willd. (Fagaceae) & Chelcu & 0.05 & 0.31 & 0.05 & 10 & 10 & 12 \\
\hline GPE23 & Umbilicus rupestris (Salisb.) Dandy (Crassulaceae) & Calighe de muru & 0.05 & 0.33 & 0.07 & 11 & 9 & 11 \\
\hline GPE02 & Allium sativum L. (Amaryllidaceae) & Azu & 0.03 & 0.29 & 0.03 & 12 & 11 & 14 \\
\hline GPE43 & Apium nodiflorum Lag. (Apiaceae) & Apieddu & 0.03 & 0.29 & 0.03 & 13 & 12 & 15 \\
\hline GPE25 & Calamintha nepeta (L.) Savi (Lamiaceae) & Nebida & 0.03 & 0.20 & 0.07 & 14 & 15 & 10 \\
\hline GPE39 & Linum usitatissimum L. (Linaceae) & Linu & 0.03 & 0.16 & 0.03 & 15 & 18 & 17 \\
\hline GPE34 & Quercus suber L. (Fagaceae) & Suerzu & 0.03 & 0.27 & 0.02 & 16 & 13 & 22 \\
\hline GPE24 & Urtica dioica L. subsp. dioica (Urticaceae) & Pistija & 0.03 & 0.18 & 0.05 & 17 & 16 & 13 \\
\hline GPE48 & Anagyris foetida L. (Leguminosae) & Giolva & 0.02 & 0.14 & 0.02 & 18 & 23 & 23 \\
\hline GPE04 & Arundo donax L. (Poaceae) & Canna & 0.02 & 0.14 & 0.02 & 19 & 24 & 24 \\
\hline GPE44 & Avena sativa L. (Poaceae) & Aena & 0.02 & 0.14 & 0.02 & 20 & 25 & 25 \\
\hline GPE49 & Camellia sp. L. (Theaceae) & Camelia & 0.02 & 0.14 & 0.02 & 21 & 26 & 26 \\
\hline GPE06 & Cistus creticus L. subsp. eriocephalus (Viv.) Greuter et Burdet (Cistaceae) & Mudeju & 0.02 & 0.14 & 0.02 & 22 & 27 & 27 \\
\hline GPE41 & Citrus limon L. (Osbeck) (Rutaceae) & Limoni & 0.02 & 0.14 & 0.02 & 23 & 28 & 28 \\
\hline GPE29 & Daphne gnidium L. (Thymelaeaceae) & Patteddu & 0.02 & 0.14 & 0.02 & 24 & 29 & 29 \\
\hline GPE37 & Daucus carota L. (Apiaceae) & Pistinaca & 0.02 & 0.14 & 0.02 & 25 & 30 & 30 \\
\hline GPE07 & Dipsacus fullonum L. (Caprifoliaceae) & Cardu aresti & 0.02 & 0.14 & 0.02 & 26 & 31 & 31 \\
\hline GPE08 & Euphorbia characias L. (Euphorbiaceae) & Lattorigu & 0.02 & 0.14 & 0.02 & 27 & 32 & 32 \\
\hline GPE09 & Ficus carica L. var. caprificus (Moraceae) & Crabufigu & 0.02 & 0.14 & 0.02 & 28 & 33 & 33 \\
\hline GPE40 & Lavatera olbia L. Alef. (Malvaceae) & Prammutza 'óina & 0.02 & 0.16 & 0.03 & 29 & 17 & 16 \\
\hline GPE47 & Nasturtium officinale R.Br. (Brassicaceae) & Ascione & 0.02 & 0.14 & 0.02 & 30 & 34 & 34 \\
\hline GPE31 & Nicotiana tabacum L. (Solanaceae) & Tabaccu & 0.02 & 0.16 & 0.03 & 31 & 19 & 18 \\
\hline GPE15 & Opuntia ficus indica L. (Cactaceae) & Figuindia & 0.02 & 0.14 & 0.02 & 32 & 35 & 35 \\
\hline GPE17 & Petroselinum crispum (Mill.) Nym. (Apiaceae) & Petrusimula & 0.02 & 0.16 & 0.03 & 33 & 20 & 19 \\
\hline GPE51 & Plantago major L. (Plantaginaceae) & Nerviadile & 0.02 & 0.14 & 0.02 & 34 & 36 & 36 \\
\hline GPE19 & Prunus spinosa L. subsp. spinosa (Rosaceae) & Pruniskedda & 0.02 & 0.16 & 0.03 & 35 & 21 & 20 \\
\hline GPE20 & Pteridium aquilinum (L.) Kuhn (Hypolepidaceae) & Filighe & 0.02 & 0.16 & 0.03 & 36 & 22 & 21 \\
\hline GPE21 & Sambucus nigra L. (Adoxaceae) & Sambuccu & 0.02 & 0.14 & 0.02 & 37 & 37 & 37 \\
\hline GPE46 & Santolina chamaecyparissus L. (Asteraceae) & Santulina & 0.02 & 0.14 & 0.02 & 38 & 38 & 38 \\
\hline GPE22 & Smilax aspera L. (Smilacaceae) & Tetti & 0.02 & 0.14 & 0.02 & 39 & 39 & 39 \\
\hline GPE42 & Smyrnium olusatrum L. (Apiaceae) & Lisandru & 0.02 & 0.14 & 0.02 & 40 & 40 & 40 \\
\hline GPE35 & Vicia faba L. (Leguminosae) & Fae & 0.02 & 0.14 & 0.02 & 41 & 41 & 41 \\
\hline GPE45 & Zea mays L. (Poaceae) & Triguìndia & 0.02 & 0.14 & 0.02 & 42 & 42 & 42 \\
\hline
\end{tabular}

${ }^{\mathrm{a}}$ (Familial nomenclature follows the Angiosperm Phylogeny Group (APG IV) 
Table 2 Non-herbal sources of remedies and their uses

\begin{tabular}{|c|c|c|c|c|}
\hline Sources & $\begin{array}{l}\text { Remedies } \\
\text { (no.) }\end{array}$ & $\begin{array}{l}\text { Ailments } \\
\text { (no.) }\end{array}$ & $\begin{array}{l}\text { Interviewees } \\
\text { (no.) }\end{array}$ & Animal treated \\
\hline Lard & 11 & 4 & 21 & Cattle $^{a}$, horses \\
\hline Salt & 10 & 7 & 14 & Cattle ${ }^{a}$, horses \\
\hline Ashes & 9 & 6 & 13 & Cattle ${ }^{a}$, horses, pigs \\
\hline Copper sulphate & 8 & 3 & 11 & $\begin{array}{l}\text { Cattle a , horses, pigs, } \\
\text { dogs, cats, hens }\end{array}$ \\
\hline Clay & 6 & 5 & 6 & $\begin{array}{l}\text { Cattle }{ }^{a} \text {, horses, } \\
\text { little pigs }\end{array}$ \\
\hline $\begin{array}{l}\text { Ozzu casu (fat obtained by boiling the } \\
\text { milk cream with flour) }\end{array}$ & 6 & 5 & 10 & $\begin{array}{l}\text { Cattle }{ }^{a} \text {, horses, pigs, } \\
\text { dogs, cats, hens }\end{array}$ \\
\hline Ozzu seu (dried peritoneum of sheep) & 5 & 3 & 6 & Cattle ${ }^{a}$, dogs \\
\hline Brewer's yeast & 4 & 4 & 10 & Cattle ${ }^{a}$, horses \\
\hline Cuttlefish bone (Sepia officinalis L.) & 3 & 2 & 6 & Cattle ${ }^{a}$, horses, pigs \\
\hline Frammentalzu (mother yeast for bakery) & 3 & 1 & 3 & Cattle $^{a}$ \\
\hline Ozzu porchinu (fat from lard) & 3 & 2 & 3 & Pigs, cows \\
\hline Ozzu brujadu (reused motor oil) & 3 & 2 & 7 & Pigs, oxen \\
\hline Knife & 3 & 3 & 3 & Cattle $^{a}$ \\
\hline Scissors & 3 & 1 & 4 & Cattle $^{a}$ \\
\hline Sugar & 3 & 2 & 4 & Cattle $^{a}$ \\
\hline Urine & 3 & 2 & 3 & Cows, pigs \\
\hline Beeswax & 2 & 1 & 2 & Cows \\
\hline Brine & 2 & 1 & 2 & Cattle $^{a}$ \\
\hline Creolin & 2 & 1 & 2 & Horses, pigs \\
\hline Cow's milk & 2 & 2 & 2 & Cattle ${ }^{a}$, pigs \\
\hline Naphtha (diesel oil) & 2 & 2 & 3 & Cattle $^{a}$ \\
\hline Needle & 2 & 1 & 6 & Cows, oxen \\
\hline Seawater & 2 & 2 & 3 & Cattle ${ }^{a}$, horses \\
\hline Soap & 2 & 2 & 2 & Cows, oxen \\
\hline Warm water & 2 & 2 & 2 & Cattle ${ }^{a}$, cat \\
\hline A bath in the river & 1 & 1 & 1 & Oxen \\
\hline Acetylsalicylic acid & 1 & 1 & 2 & Horses \\
\hline Beer & 1 & 1 & 4 & Cattle $^{a}$ \\
\hline Blood of rabbit & 1 & 1 & 1 & Pigs \\
\hline Butter & 1 & 1 & 1 & Cattle $^{a}$ \\
\hline Cicatrene & 1 & 1 & 1 & Horses \\
\hline Coal & 1 & 1 & 1 & Horses \\
\hline Coffee & 1 & 1 & 2 & Cattle $^{a}$ \\
\hline Coke & 1 & 1 & 1 & Cattle \\
\hline Ethyl alcohol & 1 & 1 & 1 & Pigs \\
\hline lodine & 1 & 1 & 1 & Cows \\
\hline Lead acetate & 1 & 1 & 1 & Horses \\
\hline Leech (Hirudo medicinalis L.) & 1 & 1 & 1 & Cattle $^{a}$ \\
\hline Lime & 1 & 1 & 1 & Cattle $^{a}$ \\
\hline Goat milk & 1 & 1 & 1 & Pigs \\
\hline Mud & 1 & 1 & 1 & $\begin{array}{l}\text { Cattle }{ }^{a} \text {, horses, pigs, } \\
\text { dog, cats, hens }\end{array}$ \\
\hline
\end{tabular}


Table 2 Non-herbal sources of remedies and their uses (Continued)

\begin{tabular}{|c|c|c|c|c|}
\hline Sources & $\begin{array}{l}\text { Remedies } \\
\text { (no.) }\end{array}$ & $\begin{array}{l}\text { Ailments } \\
\text { (no.) }\end{array}$ & $\begin{array}{l}\text { Interviewees } \\
\text { (no.) }\end{array}$ & Animal treated \\
\hline Peg & 1 & 1 & 1 & Cows \\
\hline Penicillin & 1 & 1 & 1 & Cows \\
\hline Petroleum & 1 & 1 & 2 & Cattle $^{a}$ \\
\hline Pig tail & 1 & 1 & 1 & Pigs \\
\hline Pins & 1 & 1 & 1 & Oxen \\
\hline Pumice stone & 1 & 1 & 2 & Pigs, dogs \\
\hline Red hot iron & 1 & 1 & 3 & Cattle $^{a}$, horses \\
\hline Galloping & 1 & 1 & 1 & Horses \\
\hline Red hot spike & 1 & 1 & 1 & Horses \\
\hline Rope made of goat's hair & 1 & 1 & 1 & Horses \\
\hline Rough stone & 1 & 1 & 1 & Pigs \\
\hline Silver coin (Five liras) & 1 & 1 & 1 & Cows \\
\hline Warm clothes & 1 & 1 & 1 & Horses \\
\hline Waxed thread & 1 & 1 & 1 & Pigs \\
\hline Wet clothes & 1 & 1 & 1 & Cattle $e^{a}$ \\
\hline
\end{tabular}

${ }^{\mathrm{a}}$ Cure for cows, calves, and oxen

The highest number of plant species and related remedies were used in the care of cattle (Fig. 5) as well as the highest number of non-herbal components and related remedies of non-herbal origin (Fig. 6). As shown in Fig. 7, horses, dogs, cats, and hens were prevalently treated with remedies of botanical origin while remedies from other sources outnumbered those of botanical origin for the treatment of pigs and cattle.

\section{Ethno-veterinary treatments}

The ethno-veterinary procedures against ecto- and endo-parasites are listed in Table 4, the ones still in use are marked with an asterisk. Burnt cork, olive, and lentisk oil were scrubbed on skin in the treatment of mange. Non-herbal remedies were also described, involving ozzu porchinu, copper sulphate, ozzu casu, ozzu seu, ozzu brujadu, pomice stone, and diesel oil. Olive oil was also used in the treatment of lice and forest flies in cattle and horses (Table 4). The remedies for the treatment of foot rot were only non-herbal: seawater, lime, ozzu seu, and copper sulphate. Eight out of the 28 remedies against ecto- and endo-parasites indicated in Table 4 are still in use, mainly on pigs or dogs, only two are based on plants, plum leaves to treat wounds infected by maggots in cattle and horses, and burnt cork for mange in dogs.

As shown in Table 5, gastrointestinal diseases and heart diseases were predominantly treated with plant or plant-derived medicines and decoctions of plants given as feed (mallow, barley, wild carrot) or drink (olive oil, tree mallow). Gastrointestinal diseases were also treated in horses by applying warm clothes on the belly. Bloat was generally treated by non-herbal remedies such as lard, warm water, wet clothes, diesel oil, beer, and frammentalzu (mother yeast for bakery). Bloats in cows were treated also with ground lard given as feed, sometimes with the addition of parsley and onion, then a wet cloth was put on the animal. Brewer's yeast dissolved in water was used in case of poisoning and as a refreshment in cattle. The ten remedies marked with an asterisk out of the 70 remedies for the treatment of gastrointestinal or heart diseases in Table 5 are still in use, mainly for cattle, and do not involve the use of plants except for onion mixed with lard for bloat treatment in cattle and hay for colics in cattle. Remedies for viral and bacterial diseases (Table 6) are predominantly of non-herbal origin; in the foot and mouth disease for example, pins were used to punch blisters in oxen, the seawater was used for mouth wash in cattle, and oxen were also soaked in the river for several days. Goat's milk was administered intravenously to treat swine fever. The ashes were boiled in water and applied with a bandage, or dispersed in vinegar and used for manual udder massage in cattle mastitis. The powder of cuttlefish bone (Sepia officinalis L.) put into the eye or massaged around it, was a remedy to alleviate the pain of eye infection in cattle and horses. The burnt lard and burnt sugar were used to treat hoof infections in horses and oxen. A collar made of Anagyris foetida L. was placed around the neck of dogs 
Table 3 Quantitative indices of sources other than herbal: Cl (cultural importance); RI (relative importance); RFC (relative frequency of citation)

\begin{tabular}{|c|c|c|c|c|c|c|}
\hline \multirow[t]{2}{*}{ Sources } & \multicolumn{3}{|c|}{ Indices } & \multicolumn{3}{|c|}{ Ranking } \\
\hline & $\overline{\mathrm{Cl}}$ & $\mathrm{Rl}$ & RFC & $\mathrm{Cl}$ & $\mathrm{Rl}$ & RF \\
\hline Lard & 0.32 & 0.60 & 0.35 & 1 & 1 & 1 \\
\hline Salt & 0.20 & 0.53 & 0.23 & 2 & 2 & 2 \\
\hline Copper sulphate & 0.19 & 0.37 & 0.18 & 3 & 6 & 4 \\
\hline Ozzu casu ${ }^{a}$ & 0.19 & 0.48 & 0.17 & 4 & 3 & 6 \\
\hline Ashes & 0.16 & 0.39 & 0.22 & 5 & 5 & 3 \\
\hline Brewer's yeast & 0.14 & 0.23 & 0.17 & 6 & 15 & 5 \\
\hline Ozzu brujadu b & 0.10 & 0.33 & 0.12 & 7 & 7 & 7 \\
\hline Clay & 0.09 & 0.44 & 0.10 & 8 & 4 & 8 \\
\hline Cuttlefish bone & 0.09 & 0.32 & 0.10 & 9 & 8 & 9 \\
\hline Needle & 0.09 & 0.19 & 0.10 & 10 & 16 & 10 \\
\hline Ozzu seu & 0.09 & 0.32 & 0.10 & 11 & 9 & 11 \\
\hline Scissors & 0.06 & 0.17 & 0.07 & 12 & 18 & 13 \\
\hline Seawater & 0.06 & 0.28 & 0.05 & 13 & 13 & 19 \\
\hline Sugar & 0.06 & 0.29 & 0.07 & 14 & 10 & 14 \\
\hline Frammentalzu $^{\mathrm{d}}$ & 0.04 & 0.16 & 0.05 & 15 & 19 & 15 \\
\hline Knife & 0.04 & 0.28 & 0.05 & 16 & 11 & 16 \\
\hline Ozzu porchinu e & 0.04 & 0.28 & 0.05 & 17 & 12 & 17 \\
\hline Red hot iron & 0.04 & 0.16 & 0.05 & 18 & 20 & 18 \\
\hline Urine & 0.04 & 0.16 & 0.05 & 19 & 21 & 20 \\
\hline Acetylsalicylic acid & 0.03 & 0.15 & 0.03 & 20 & 22 & 21 \\
\hline Beeswax & 0.03 & 0.15 & 0.03 & 21 & 23 & 22 \\
\hline Brine & 0.03 & 0.15 & 0.03 & 22 & 24 & 23 \\
\hline Coffee & 0.03 & 0.15 & 0.03 & 23 & 25 & 24 \\
\hline Creolin & 0.03 & 0.15 & 0.03 & 24 & 26 & 25 \\
\hline Cow's milk & 0.03 & 0.27 & 0.03 & 25 & 14 & 26 \\
\hline Petroleum & 0.03 & 0.15 & 0.03 & 26 & 27 & 27 \\
\hline Soap & 0.03 & 0.15 & 0.03 & 27 & 28 & 29 \\
\hline Water & 0.03 & 0.15 & 0.03 & 28 & 30 & 30 \\
\hline A bath in the river & 0.01 & 0.14 & 0.02 & 29 & 31 & 31 \\
\hline Beer & 0.01 & 0.17 & 0.07 & 30 & 17 & 12 \\
\hline Blood of rabbit & 0.01 & 0.14 & 0.02 & 31 & 32 & 32 \\
\hline Butter & 0.01 & 0.14 & 0.02 & 32 & 33 & 33 \\
\hline Cicatrene & 0.01 & 0.14 & 0.02 & 33 & 34 & 34 \\
\hline Coal & 0.01 & 0.14 & 0.02 & 34 & 35 & 35 \\
\hline Coke & 0.01 & 0.14 & 0.02 & 35 & 36 & 36 \\
\hline Ethyl alcohol & 0.01 & 0.14 & 0.02 & 36 & 37 & 37 \\
\hline Galloping & 0.01 & 0.14 & 0.02 & 37 & 38 & 38 \\
\hline lodine & 0.01 & 0.14 & 0.02 & 38 & 39 & 39 \\
\hline Lead acetate & 0.01 & 0.14 & 0.02 & 39 & 40 & 40 \\
\hline Leech (Hirudo medicinalis) & 0.01 & 0.14 & 0.02 & 40 & 41 & 41 \\
\hline Lime & 0.01 & 0.14 & 0.02 & 41 & 42 & 42 \\
\hline Goat milk & 0.01 & 0.14 & 0.02 & 42 & 43 & 43 \\
\hline
\end{tabular}

Table 3 Quantitative indices of sources other than herbal: Cl (cultural importance); RI (relative importance); RFC (relative frequency of citation) (Continued)

\begin{tabular}{|c|c|c|c|c|c|c|}
\hline \multirow[t]{2}{*}{ Sources } & \multicolumn{3}{|c|}{ Indices } & \multicolumn{3}{|c|}{ Ranking } \\
\hline & $\mathrm{Cl}$ & $\mathrm{Rl}$ & RFC & $\mathrm{Cl}$ & $\mathrm{RI}$ & RFC \\
\hline Mud & 0.01 & 0.14 & 0.02 & 43 & 44 & 44 \\
\hline Naphtha (diesel oil) & 0.01 & 0.14 & 0.02 & 44 & 45 & 45 \\
\hline Peg & 0.01 & 0.14 & 0.02 & 45 & 46 & 46 \\
\hline Penicillin & 0.01 & 0.14 & 0.02 & 46 & 47 & 47 \\
\hline Pig tail & 0.01 & 0.14 & 0.02 & 47 & 48 & 48 \\
\hline Pins & 0.01 & 0.14 & 0.02 & 48 & 49 & 49 \\
\hline Pumice stone & 0.01 & 0.15 & 0.03 & 49 & 29 & 28 \\
\hline Red-hot spike & 0.01 & 0.14 & 0.02 & 50 & 50 & 50 \\
\hline Rope made of hair (from goat) & 0.01 & 0.14 & 0.02 & 51 & 51 & 51 \\
\hline Rough stone & 0.01 & 0.14 & 0.02 & 52 & 52 & 52 \\
\hline Silver coin (Five liras) & 0.01 & 0.14 & 0.02 & 53 & 53 & 53 \\
\hline Warm clothes & 0.01 & 0.14 & 0.02 & 54 & 54 & 54 \\
\hline Waxed thread & 0.01 & 0.14 & 0.02 & 55 & 55 & 55 \\
\hline Wet clothes & 0.01 & 0.14 & 0.02 & 56 & 56 & 56 \\
\hline
\end{tabular}

${ }^{\mathrm{a}}$ Fat obtained by boiling the milk cream with flour

${ }^{\mathrm{b}}$ Reused motor oil

'Dried peritoneum of sheep

${ }^{\mathrm{d}}$ Mother yeast for bakery

e Fat from lard

with respiratory diseases, although these affections were also cured by using the decoction of either mallow or pellitory of the wall, or the fumes generated by burning leaves of wild fig trees. Only one of the 40 remedies against viral or bacterial diseases in Table 6 is still in use and it does not imply the use of plants. The ethno-veterinary remedies for treating wounds, gonadectomy, sprains, bruises, pimples, and swelling involved both the use of plants or substances of non-herbal origin (Table 7). Burnt lard, coal, acetylsalicylic acid, cicatrene, and ozzu casu were applied and massaged on the wounds in horses, pigs, bovines, and dogs. Ground fresh leaves of navelwort, elderberry, powder from stem, or the bark of lentisk was used to promote wound healing. To ease the effect of castration in pigs, the interviewees referred about the use of ozzu brujadu (reused motor oil), ozzu casu, urine, and ashes alone or added with olive oil; however, only one plant (mallow) was utilized to disinfect, heal, and soften the skin. Sprains and bruises were mainly cured with parts of plant or plant derivatives with the exception of sprains in cattle and equines where the cortex of Quercus pubescens Willd. was boiled with salt and vinegar, ground, mixed with clay, and then applied to the sore area wrapped with a bandage (Table 7). Skin lesions were treated with beeswax with or without the addition of ozzu porchinu and 


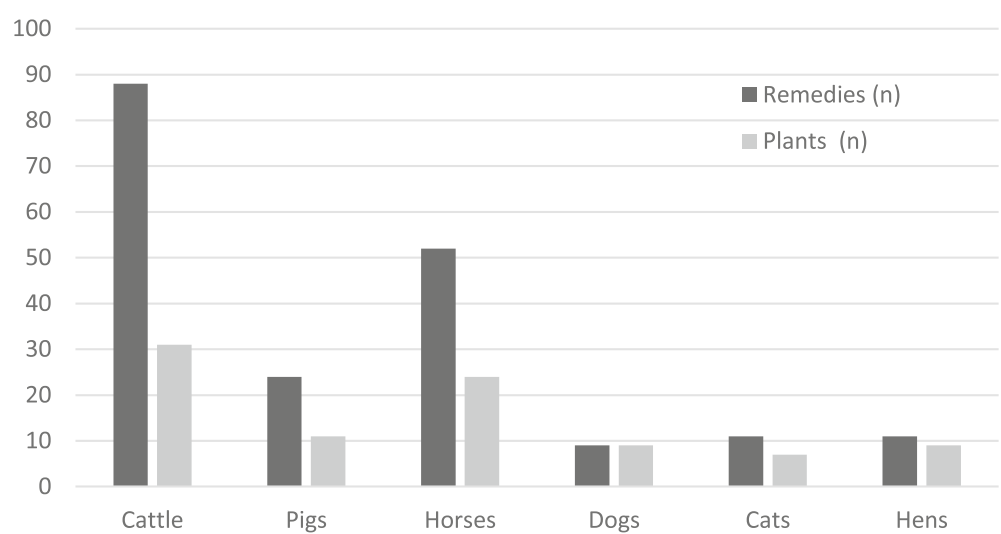

Fig. 5 Number of plant species and related remedies used for the care of each animal species

ozzu seu. To the swelling limbs of horses was applied clay alone or mixed with vinegar and salt, and lead acetate alone or added with water. Eight out of the 59 remedies indicated in Table 7 for the treatment of wounds, sprains, and bruises are still in use, mainly for cattle, horses, or dogs, three of them involved the use of plants, camellia for wounds in horses, and sarsaparilla and greater plantain for pimples in calves and fissures in cows. Further, farmers' traditional uses of plants are shown in Table 8, and among them, ivy leaves are given to cows after giving birth, and stems of Euphorbia characias L. are used for catching eels. Twenty-seven of the reported remedies were still in use, those marked with an asterisk in Tables 4, 5, 6 and 7, mainly those employed for the treatment of gastrointestinal diseases, ecto- and endo-parasites, wounds, sprains, and bruises. The vast majority of the remedies was for topical administration (61.2\%); fewer $(37.8 \%)$ were for internal use (e.g. swallowed), and only $1 \%$ of the treatments implied the exposure to fumes.

\section{Discussion}

We developed the discussion about Sardinian ethno-veterinary practices considering the sharing of knowledge with Mediterranean, European, and extra-European countries, the actual use of such practices, and the eventual validation in scientific literature of the components of remedies.

\section{Use of animal body parts and/or animal substances}

The therapeutic properties and uses of marine invertebrates were well known in the ancient Greek world and early Byzantine times; in particular, pulverized cuttlefish bone has been used in various eye itches and diseases [42]. The same use of pulverized cuttlefish bone was referred in our study, and it is supported by a recent review on anti-inflammatory, immune-modulatory, and wound healing properties of mollusks [43].

A vast amount of literature about leech therapy exists; active substances in leeches to prevent blood coagulation

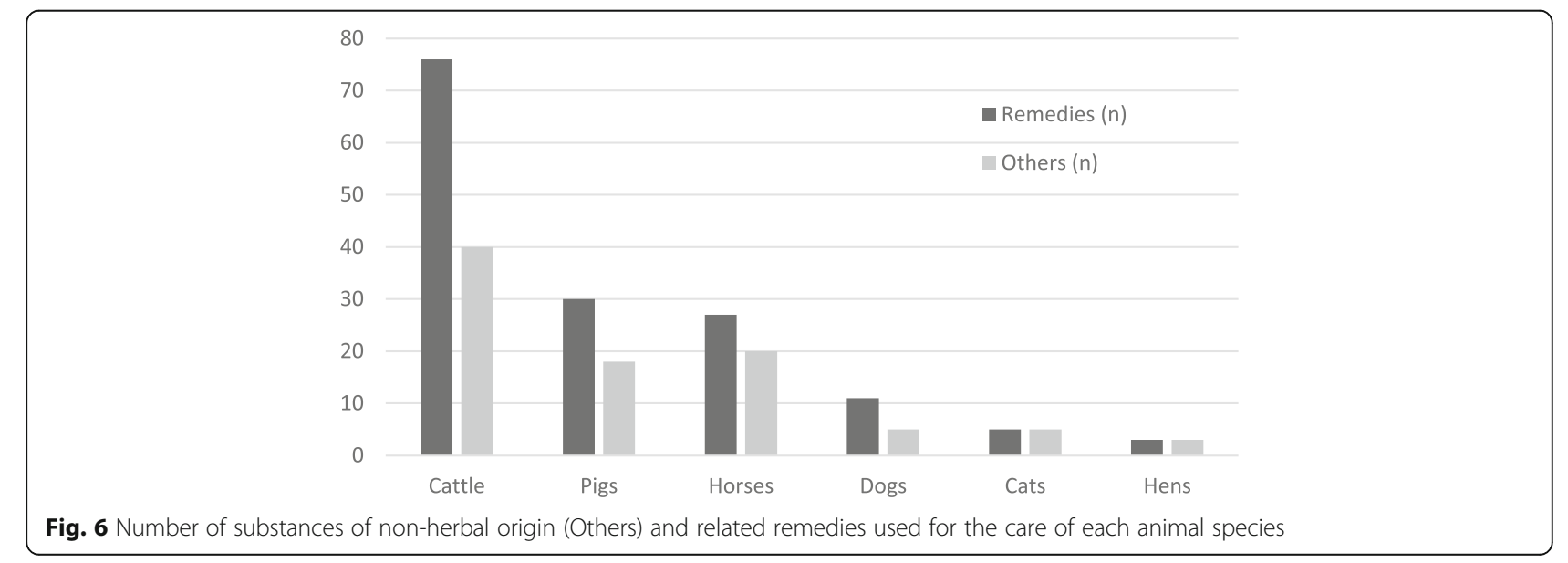




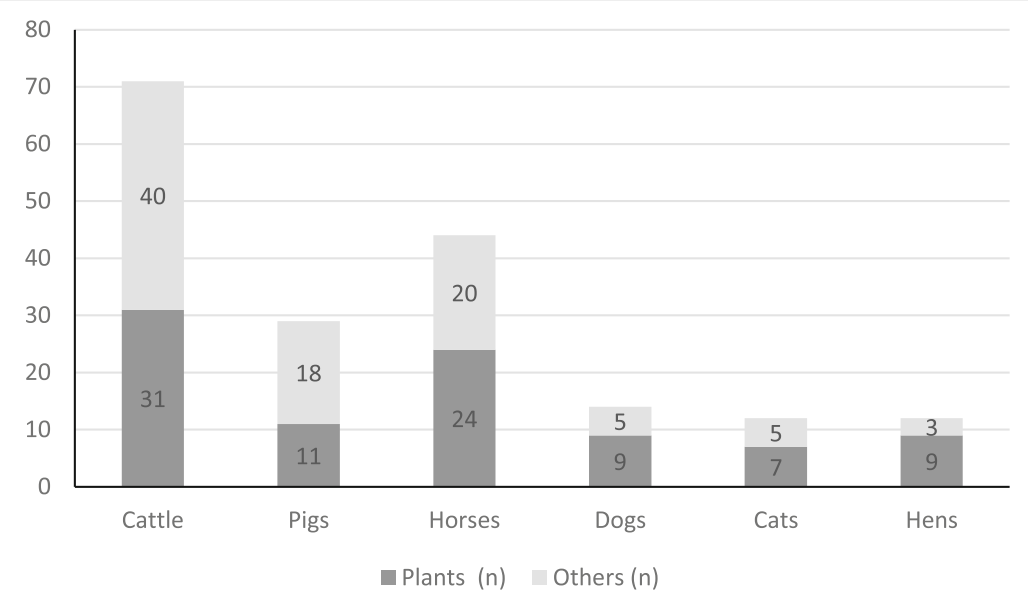

Fig. 7 Comparison of the number of plant species (Plants) and substances of non-herbal origin (Others) used for the care of each animal species

and treat osteoarthritis and other ailments in humans have received considerable attention [44], and in our survey, leeches were used to treat cows having high blood pressure.

Pig fat (lard) is an important component of several remedies for skin conditions in southern Italy; in addition to its emollient properties, it is also reported to be a useful vulnerary agent in the treatment of both animals and humans [45]. In our survey, lard was used to treat mange on pigs, bloat on cattle, hoof infection, and wounds on horses. Similarly, it has been used in Brazil for scabies, skin diseases, welling, burns, and wounds [46, 47]. Sheep suet has been also used for many disorders, including inflammation, sprains, and swelling [47], while in our study ozzu seu (dried peritoneum of sheep) was indicated for mange, foot rot, and fissures. The same authors have reported the use of milk of goat to treat weakness and malnutrition; in Sardinia, it was used to treat swine fever. Goat milk cream mixed with the pounded roots of Panicum turgidum Forssk. was applied topically to treat deep wounds and fractures in Africa [48].

Urine has been reported [49] as wound disinfectant, and that from cows has been shown to possess antioxidant and antibacterial properties [49]; in our survey, its use was recommended for porcine gonadectomy and for bovine pimples. Beeswax has been suggested to be effective for skin, for digestive disorders, and snake bites [44]. In Spain [6, 29], beeswax was used for cracks in the udder of cows, similar to our interviewees that used it to treat fissures in cows.

The use of animal parts or animal-derived products (ozzu seu, lard, ozzu porchinu, ozzu casu) is still practiced in Sardinian ethno-veterinary preparations and seven out of the 27 remedies still in use included such components.

\section{Use of mineral substances}

The use of copper sulphate has been reported in Southern Italy either as a ground powder or dissolved in vinegar or with water and salt applied to cracked hooves or to the chapped skin surrounding the hooves of livestock [45]. In our study, copper sulphate was used for the treatment of mange in dogs, cattle, and pigs, for foot rot in cattle and pigs, and for wounds in pigs and dogs. Kyrgyz (central Asia) people have used blue stone or copper sulphate, white clay, and solution of sodium chloride to disinfect either the oral cavity of animals affected by foot and mouth disease or their external wounds [50]. A solution of copper sulphate has been used as anti-septic for wounds, while combustible sulphur has been employed to treat scabies [50]. It has been attested the use of a solution of copper sulphate in water to kill intestinal parasites [51]. Clay added with salt has been indicated to treat mastitis in cattle in Romania [4]; in our study, that remedy was used to treat gastrointestinal diseases in weaner pigs, hoof infections in cattle, sprains in cattle and horses, and swelling limbs in horses.

We reported the use of mud in the treatment of foot and mouth disease, the same use has been made in India [51]. Studies have demonstrated that mud therapy lowers the levels of inflammatory mediators and has a positive effect on antioxidant condition; recent investigations on the action mechanism of these products explain the reason of the empirical use of mud since ages [52].

Remedies were used in Sahara region such as bitumen and exhaust engine oil (based on products made available with modernization and globalization) to treat mange, and as insecticides against tick and flea infestations; and also cauterizations performed with iron tools to treat mastitis, abscesses, and inflammations [53], likewise the remedies reported by Sardinian farmers in our 


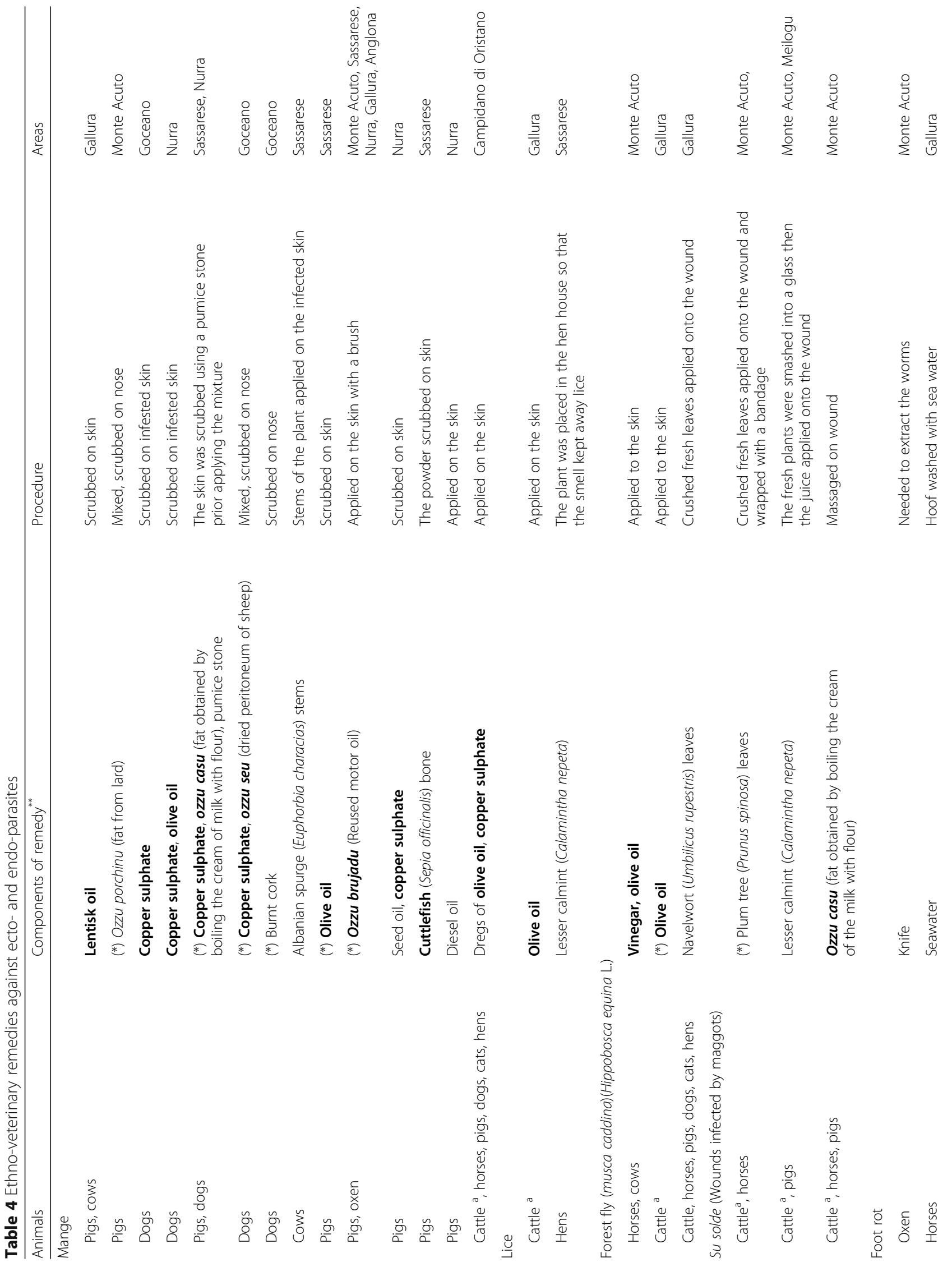




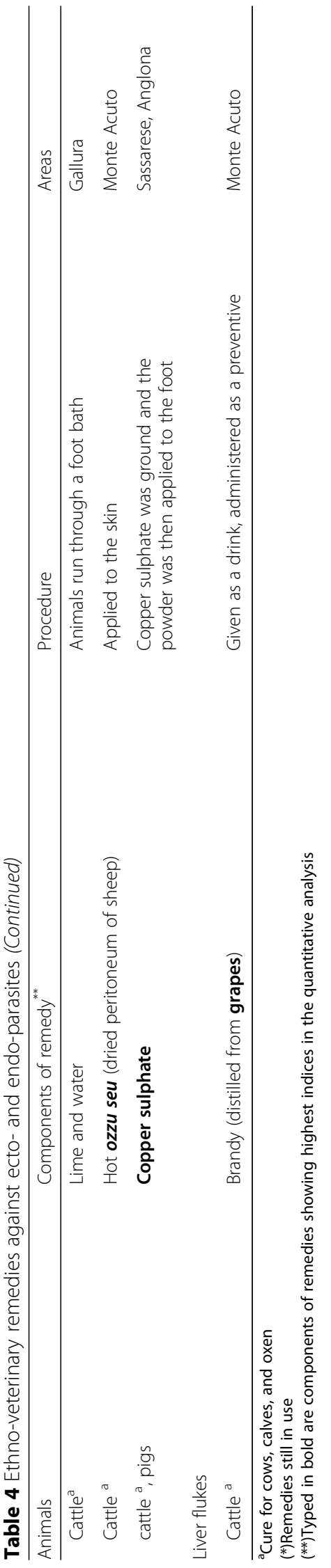




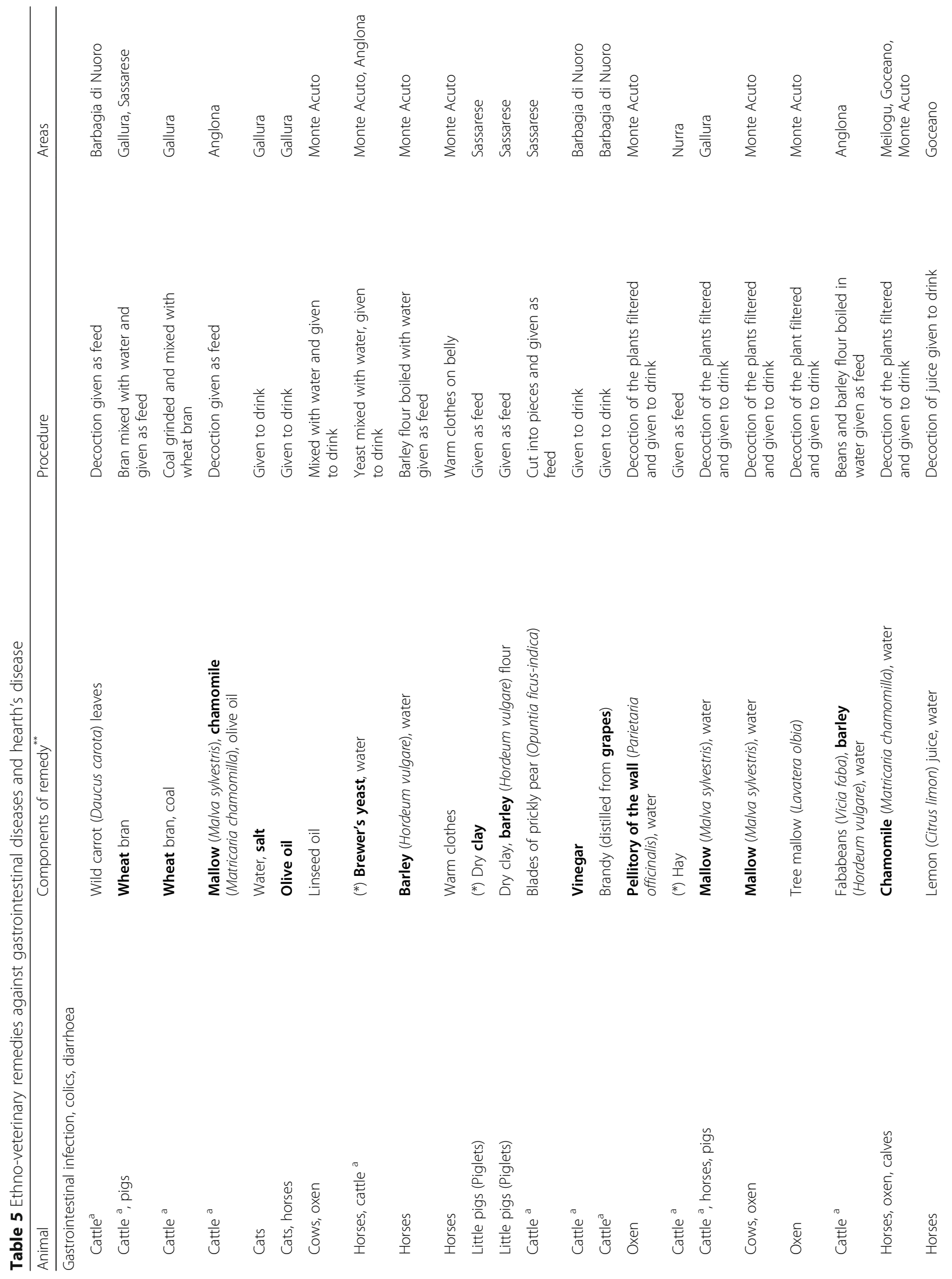




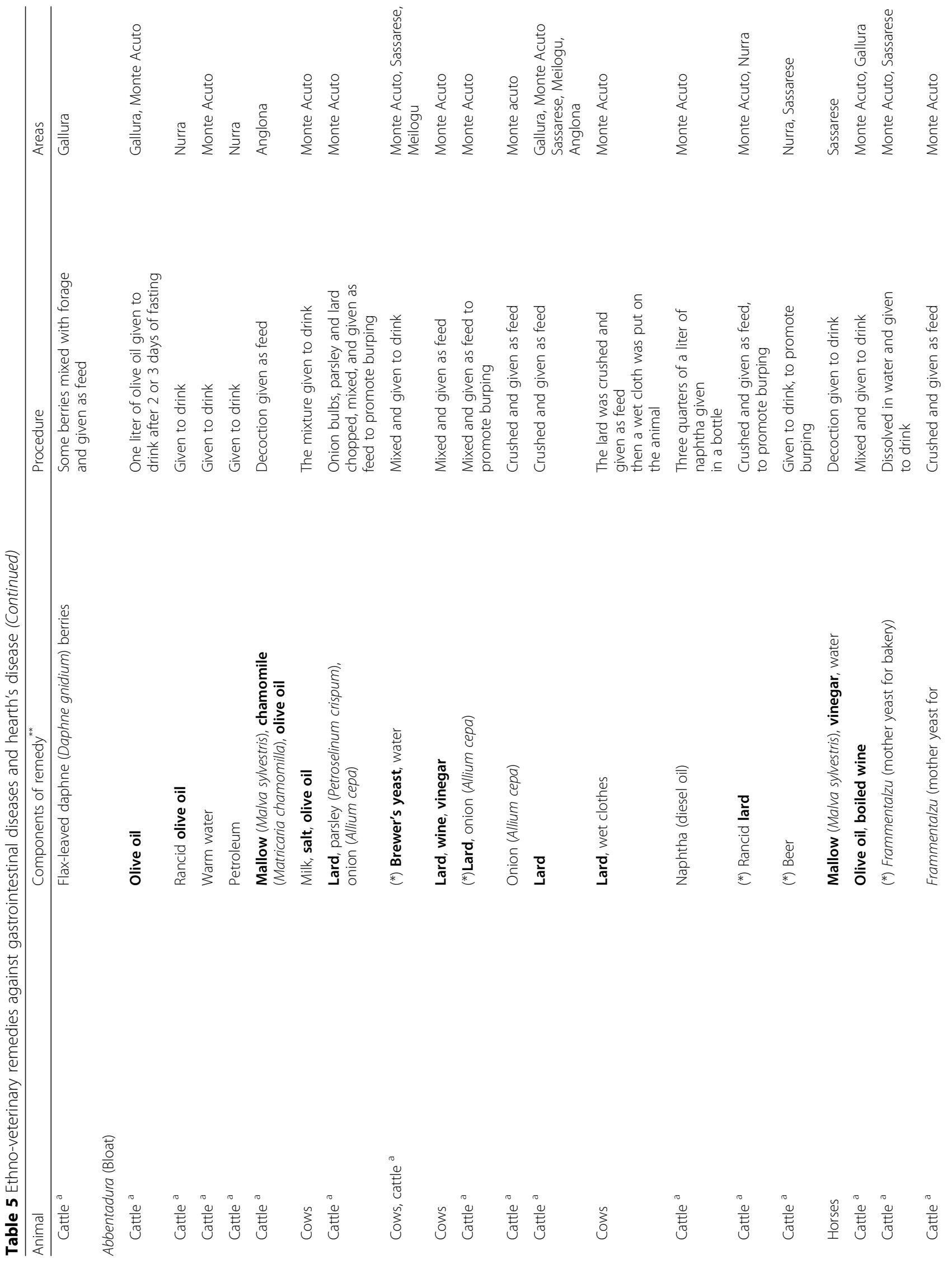




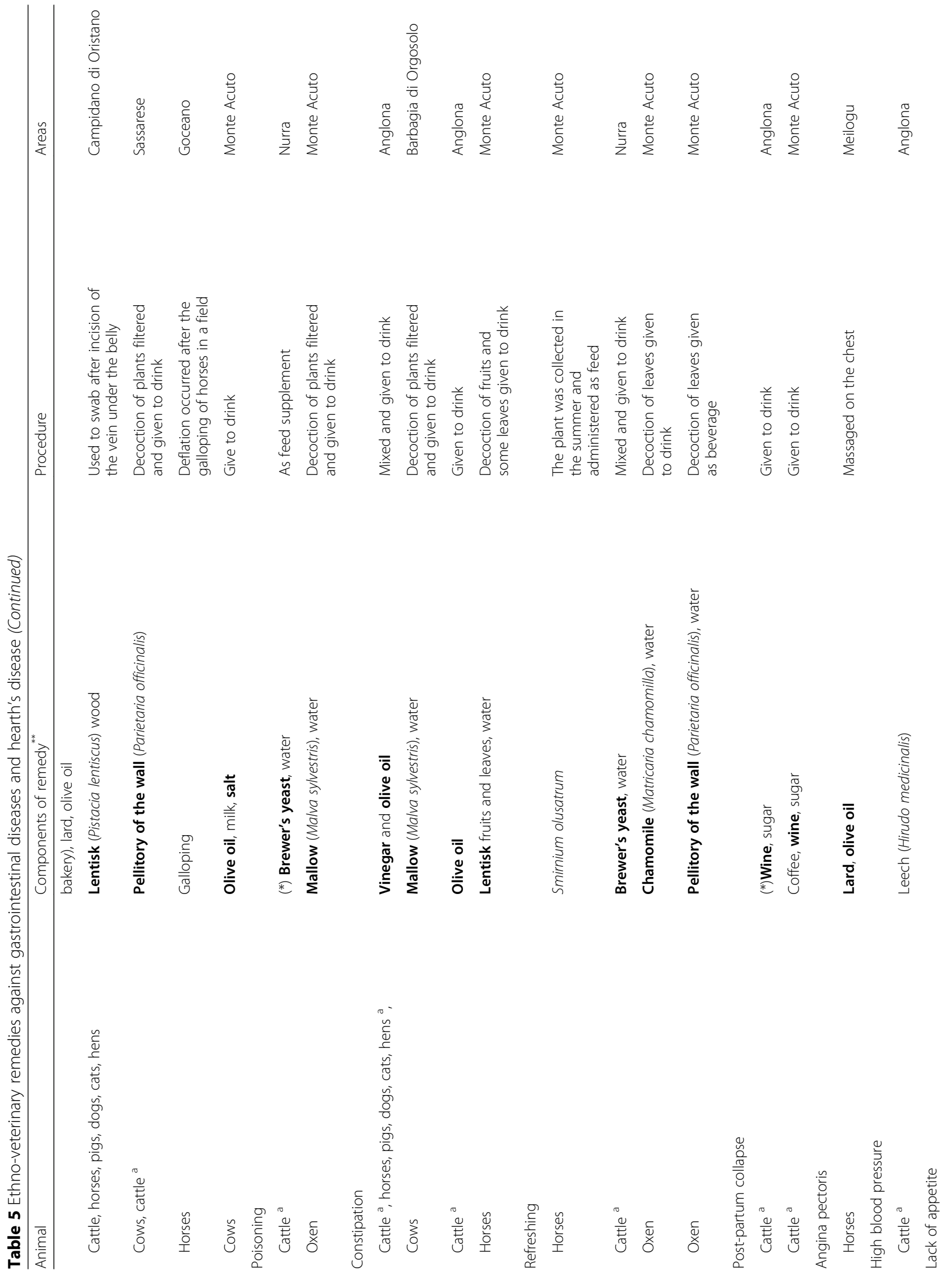




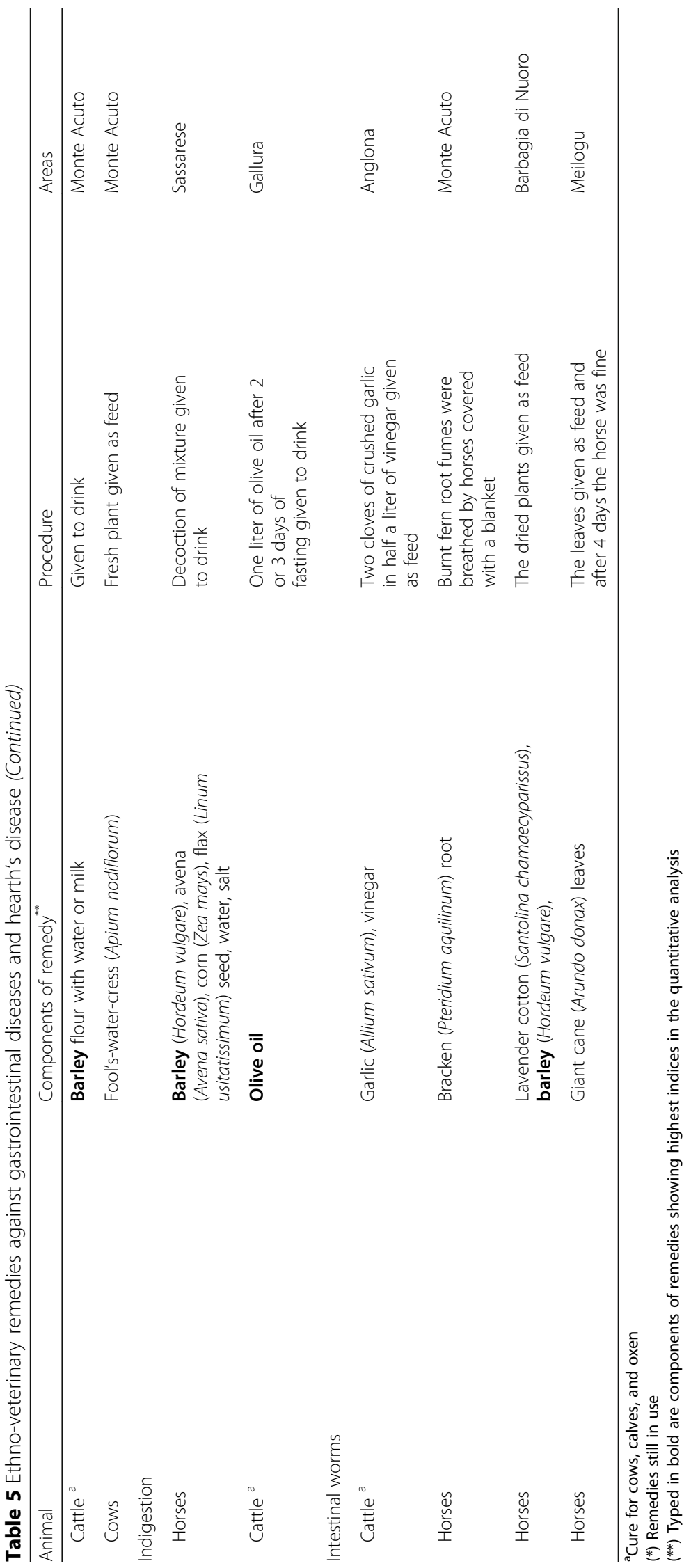




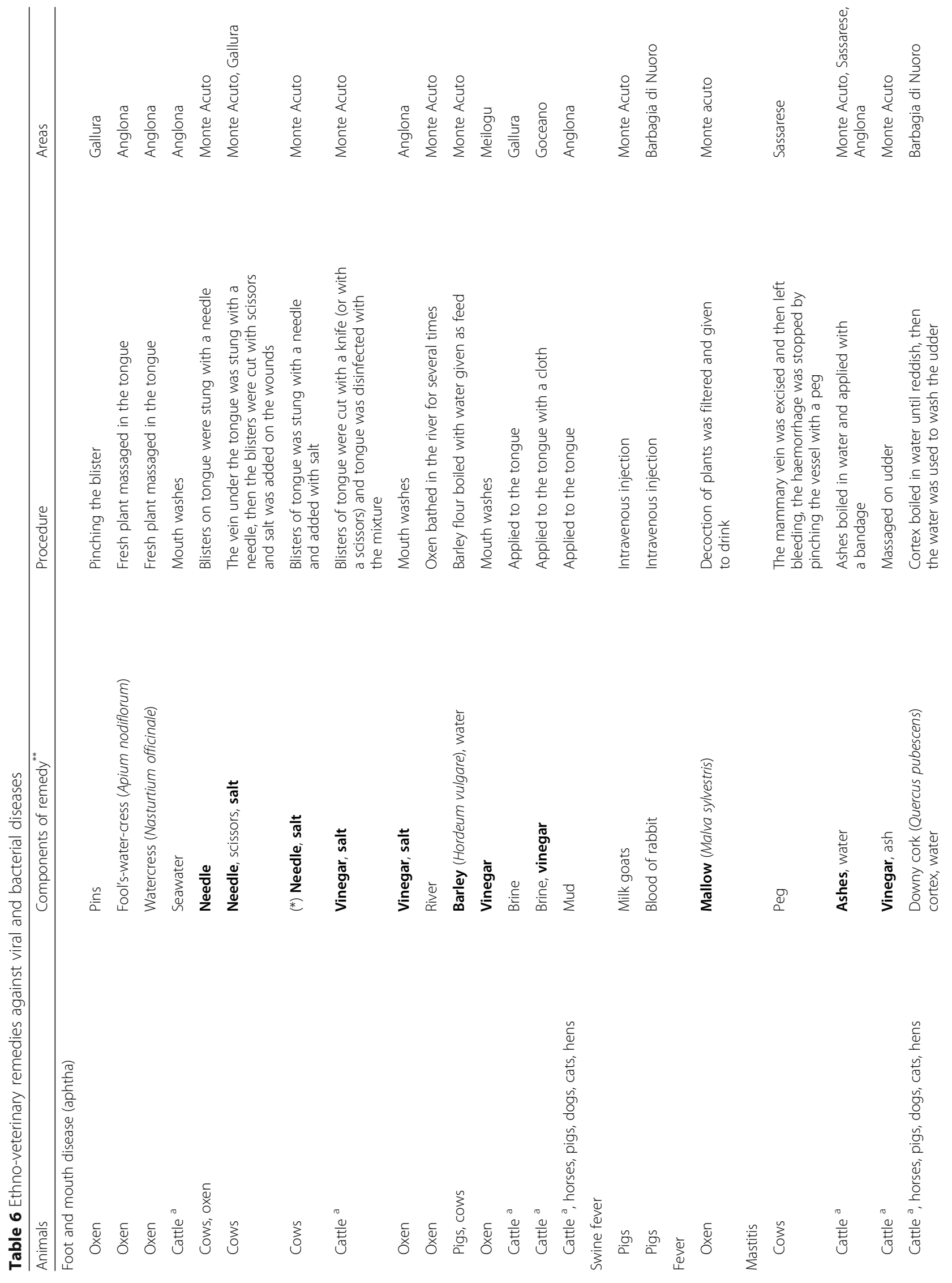




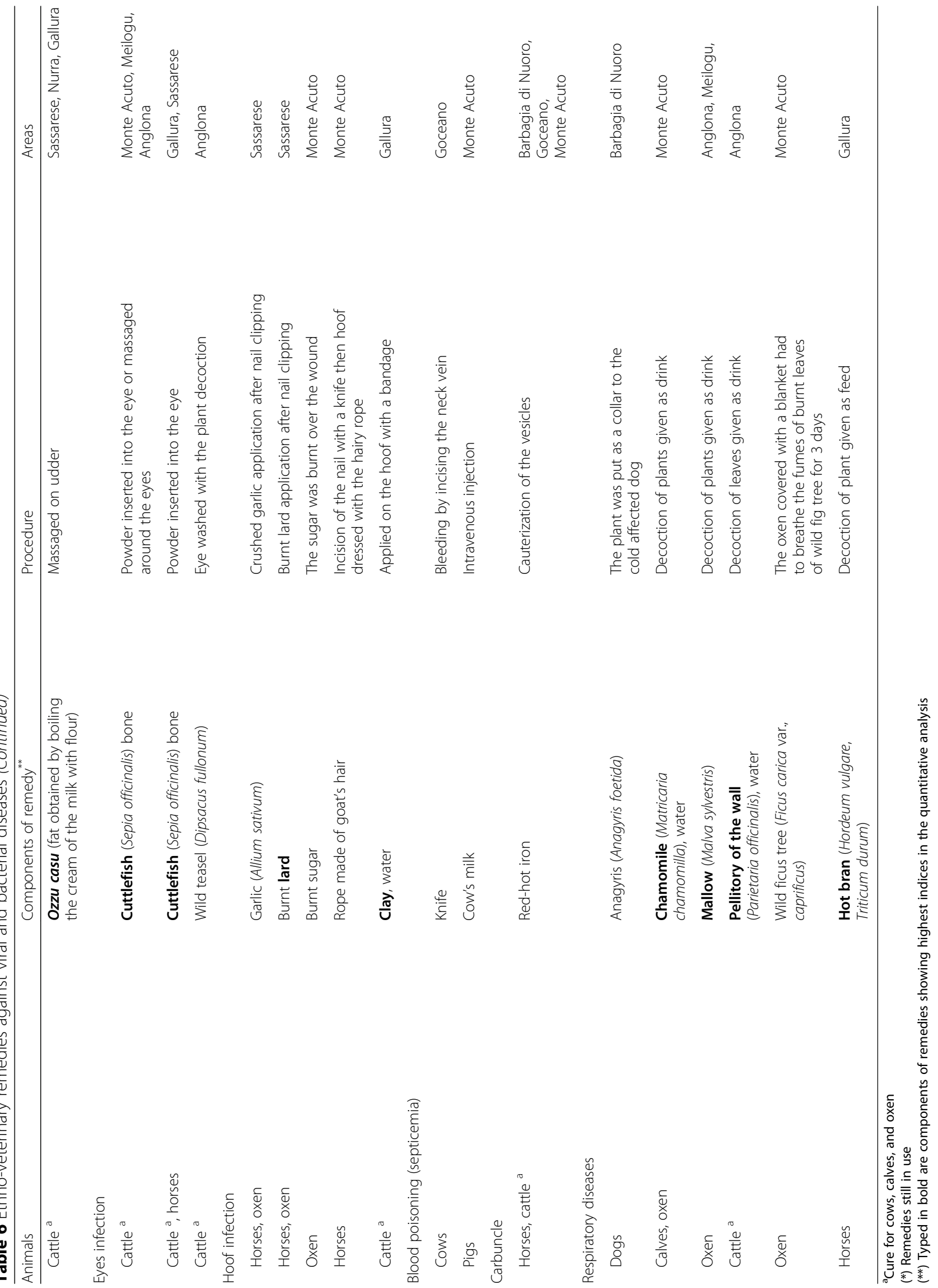




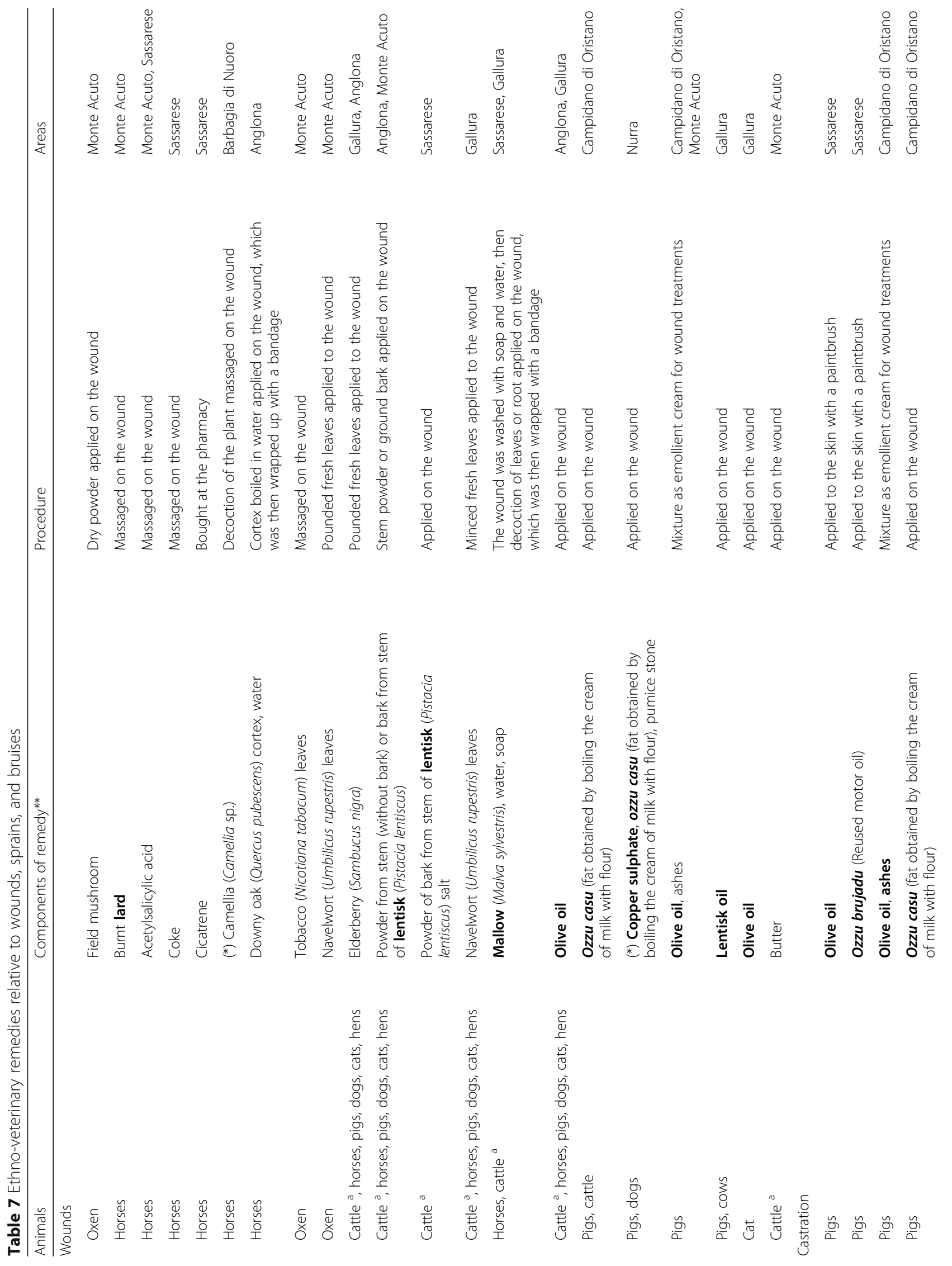




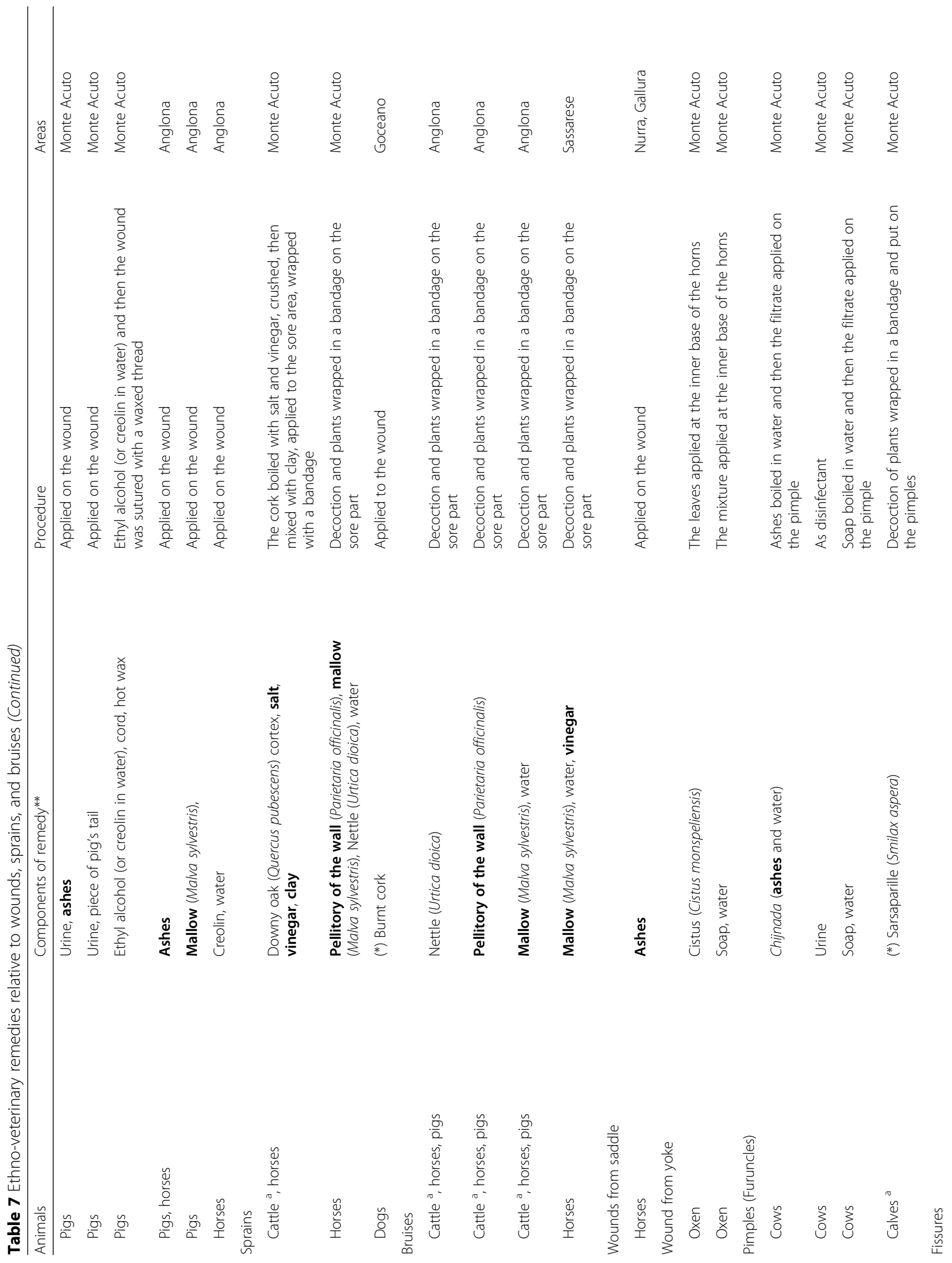




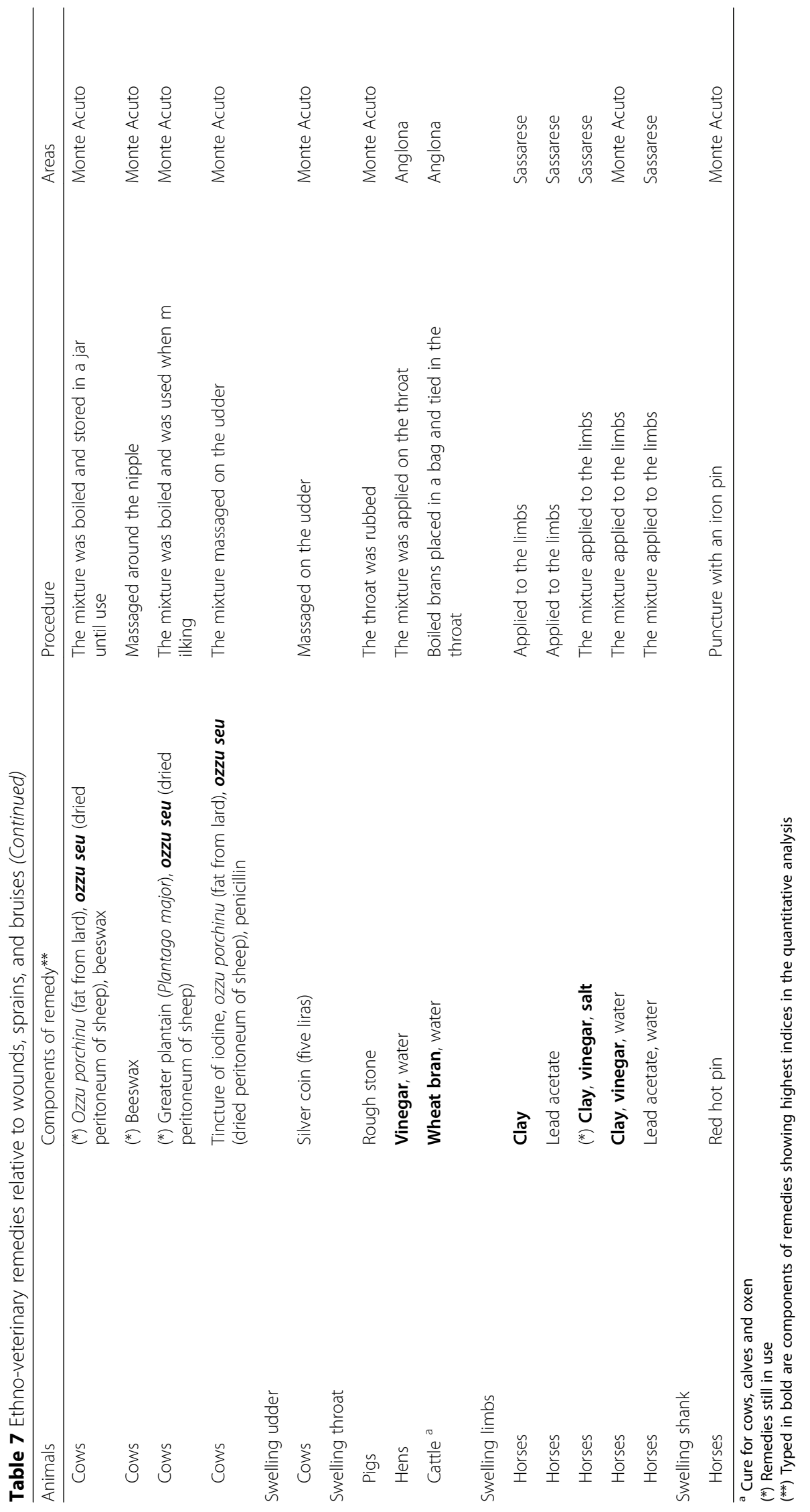


Table $\mathbf{8}$ Other traditional uses of plants suggested by farmers

\begin{tabular}{lll}
\hline Materials & Uses & Areas \\
\hline $\begin{array}{l}\text { Tree wormwood } \\
\text { (Artemisia arborescens) } \\
\text { flowers }\end{array}$ & To prepare spirits & Anglona \\
$\begin{array}{l}\text { Ivy (Hedera helix) } \\
\text { Given to cows after } \\
\text { giving birth } \\
\text { bran }\end{array}$ & $\begin{array}{l}\text { Barbagia di } \\
\text { Nuoro }\end{array}$ \\
$\begin{array}{l}\text { Albanian spurge } \\
\text { (Euphorbia characias) } \\
\text { stems }\end{array}$ & $\begin{array}{l}\text { Stems used for } \\
\text { catching eels }\end{array}$ & Gallura \\
\hline
\end{tabular}

study. Salt dissolved in warm water and its topical application to bruises, muscular pains, and rheumatisms has been reported in Albania [54]; in our survey, in addition to these usages, it was suggested also for gastrointestinal problems, for foot and mouth disease and for wounds.

Only six remedies containing mineral substances are still in use: copper sulphate for mange in dogs, and, together with pumice stone for wounds in pigs and dogs, clay for diarrheoa in piglets and swelling limbs in horses; ozzu brujadu for mange in pigs and oxen; salt for foot and mouth disease in cows. While other nine remedies still in use, instead of mineral substances, include natural components (cork, olive oil, brewer yeast, frammentalzu, hay, wine, sugar).

In the case of cauterization medicine, a hot iron was used for curative purposes [55]; this tradition still survives in the Mid-Eastern veterinary practice [7]. In our study, a red-hot iron was indicated for the treatment of carbuncle in horses and cattle.

\section{Use of plants or plant- derivatives}

In our survey, we recorded 42 plant taxa and 116 ethno-veterinary preparations with plants or plant-derived products as ingredients. In the survey carried out in circum-Mediterranean areas (eight nations) within the RUBIA project, 136 ethno-veterinary preparations and 110 plant taxa used for traditional animal health care have been recovered [2]. Twenty-six of the plant taxa in our ethno-veterinary survey were not mentioned in the report of the RUBIA project. In the review of plants used in folk veterinary medicine in Italy, Viegi [56] does not mention 14 of the species we recorded in our ethno-veterinary survey. Among the Sardinian ethno-botanic traditions investigated by Atzei [57], the species Apium nodiflorum Lag., Daucus carota L., Dipsacus fullonum L., Nasturtium officinale R.Br., Petroselinum crispum (Mill.) Nym., Prunus spinosa L., and Camellia sp. were not mentioned for ethno-veterinary uses.

In Spain, the remedy for pneumonia in cattle consisted in burning the aerial part of Lavandula pedunculata
(Mill.) Cav. with sugar, to generate smoke [58]; similarly, Sardinia respiratory diseases in oxen were treated by fumigations of leaves of Ficus carica L.var. caprificus. Topical application of Euphorbia oxyphylla Boiss. latex has been used to treat wounds in equines [58], while in our study Camellia, tobacco leaves, Quercus pubescens cortex, navelwort leaves, elderberry leaves, powder of bark from stem of lentisk, and mallow were used for the same purpose. We found that Daphne gnidium L. was a remedy for gastrointestinal diseases in cattle, while in Spain it has been used to treat lambs with diarrhoea [58].

Consistent to our finding, it has been reported that for the traditional matanza (slaughter of swine and preparation of hams and sausage) pig fattening was implemented by surgical castration [58]. Nowadays, gonadectomy is performed by qualified veterinarians, but in the past, it was a duty for the most experienced family members. However, the procedure is not devoid of complications, and to minimize the risk of infections and inflammation, the succulent leaves of Umbilicus rupestris (Salisb.) Dandy have been used in Spain [58]. U. rupestris is a plant widely used according to ethno-veterinary studies in the Mediterranean region [13, 14, 59]. Our survey showed that mallow or olive oil were used for the same purposes, alongside non-herbal treatments (urine, ash, ozzu casu, reused motor oil), whereas $U$. rupestris was employed for other types of wounds in cattle, horses, pigs, dogs, cats, and hens. The use of Malva sylvestris in the management of gastrointestinal diseases has been shown to be a quite broadly diffused practice in Spain [58] and Argentina [18], and our findings reported the same use.

The use of Urtica dioica L. has been documented as a galactogogue for cows in Italy [60]; in our survey, it was used for sprains in horses and bruises in cattle, horses, and pigs.

The widespread use of Allium sativum L. as vermicide has been well-documented in Romania [4], in Spain [61], in Algeria [2], and in Italy [14, 62], and our data showed its use in the treatment of intestinal worms in cattle and for hoof infection in horses and oxen. The use of garlic for bronchitis, fever, and indigestion in equines has been also reported in the Far East [63].

In the Romanian ethno-veterinary practices, Petroselinum crispum (Mill.) Nym has been used to improve rumination [4] while our findings showed it was used with lard and onion for bloat in cattle.

According to our interviewees, coffee would help in post-partum collapse. In Switzerland, it has been described for the treatment of gastrointestinal troubles, colic, abdominal pain, or diarrhoea [1].

The topical administration of $N$. tabacum L. leaves has been reported in our study for wounds in oxen; in Iran it was used for external and internal parasite disorders of dogs [64]; in India it was considered effective against 
ecto-parasites [65], while it was used for distemper, scabies, and parasitosis in Argentina [18].

In Italy, Zea mays L. was indicated for skin problems and wounds on cattle and for gastrointestinal complaints in horses [56], and in our survey, it was used as a remedy for indigestion in horses; in Pakistan, it was considered useful for anorexia, hematuria, weakness, and wounds in horses [63]. The use of camellia decoctions to treat wounds of horses reported in our survey cannot be found in other European or Mediterranean ethno-veterinary surveys; a traditional use of camellia in East Asia was to soothe skin [66].

Sugar has been described for the treatments of heart problem in horses in Albania [54]; Sardinian farmers, in our study, used it for cattle post-partum collapse and horse hoof infections.

Only few ethno-veterinary remedies implying the use of plants or part of plants (Prunus spinosa, Allium coepa, Smilax aspera, Plantago major, Camellia, Olea europaea, Vitis vinifera, Quercus suber), are still in use in Sardinia.

\section{Conclusion}

The Mediterranean rural culture still maintains knowledge about many traditional herbal and non-herbal remedies for curing or treating animals, although in recent years the development of modern livestock farming technologies, administrative controls, and the denial of popular remedies have led to neglect those practices. Considering that only 27 out of the 197 reported remedies are still in use and that the knowledge was mostly hold by the most aged informants, it can be easily foreseen the loss of knowledge about such traditional ethno-veterinary practices in Sardinia. Our survey recovering ancient ethno-veterinary traditions can prevent their disappearance. It is to remark that only a few out of the 27 remedies still in use imply the utilization of plants; as a consequence, the ethno-botanic knowledge related to traditional animal care is going to be lost. The knowledge of traditional ethno-veterinary practices can be a source of useful information for the isolation of natural extracts to develop new products for health care and well-being of animals. Our data may represent novel opportunities for performing further studies, starting from ancient traditions, aimed at uncovering effective natural sources of bio-antioxidants, and new natural products for the well-being and health care of domestic animals. In agreement to Meyer-Rochow [44], the challenge is to identify those traditional healing methods that do have something to offer before nobody knows anything anymore about them and such healing methods have disappeared from the collective memory of a people.

\section{Acknowledgements}

The authors thank all the interviewees for sharing their knowledge. We dedicate this study in memory of Professor Giovanni Palmieri from the Sassari University.

\section{Funding}

This work was supported by the Sardinian Bank Foundation - Grant no. $66 / 4181 / 02$.

\section{Availability of data and materials}

All data generated or analyzed in this study are included in this article.

\section{Authors' contributions}

SB was responsible of the research and made the data collection and analysis. GAR participated in the data collection. MDIM cooperated in the data analysis. GP cooperated in the data analysis. All authors contributed to the preparation and critical revision of the manuscript. All authors read and approved the final manuscript.

\section{Ethics approval and consent to participate}

All actors involved in this research were informed about the aims of the study and accepted to participate to the interviews.

\section{Consent for publication \\ Not applicable.}

\section{Competing interests}

The authors declare they have no competing interests.

\section{Publisher's Note}

Springer Nature remains neutral with regard to jurisdictional claims in published maps and institutional affiliations.

\section{Author details}

${ }^{1}$ Istituto per il Sistema Produzione Animale in Ambiente Mediterraneo CNR-ISPAAM, Traversa La Crucca 3, località Baldinca, 07100 Sassari, Italy. ${ }^{2}$ Present address: Wellcome Trust Centre for Cell Biology, University of Edinburgh, Edinburgh, UK.

Received: 2 February 2018 Accepted: 10 July 2018

Published online: 20 July 2018

\section{References}

1. Bischoff T, Vogl CR, Ivemeyer S, Klarer F, Meier B, Hamburger M, Walkenhorst M. Plant and natural product based homemade remedies manufactured and used by farmers of six central Swiss cantons to treat livestock. Livest Sci. 2007;189:110-25.

2. Pieroni A, Giusti M, de Pasquale C, Lenzarini C, Censorii E, Gonzáles-Tejero M, Sánchez Rojas CP, Ramiro Gutiérrez JM, Skoula M, Johnson C, Sarpaki A, Della A, Paraskeva Hadijchambi D, Hadjichambis A, Hmamouchi M, El Jorhi S, El Demerdash M, El Zayat M, Al Shahaby O, Houmani Z, Scherazed M. RUBIA project: Circum-Mediterranean cultural heritage and medicinal plant uses in traditional animal healthcare: a field survey in eight selected areas within the RUBIA project. J Ethnobiol Ethnomed. 2006;2:15.

3. Lans C, Nancy T, Gerhard B, Grant L, Karla G. Ethnoveterinary medicines used for horses in Trinidad and in British Columbia, Canada. J Ethnobiol Ethnomed. 2006;2:1.

4. Bartha SG, Quave CL, Balogh L, Papp N. Ethnoveterinary practices of Covasna County, Transylvania, Romania. J Ethnobiol Ethnomed. 2015; 11(1):35.

5. Anyinam C. Ecology and ethnomedicine: exploring links between current environmental crisis and indigenous medical practices. Soc Sci Med. 1995; 40:321-9.

6. Pieroni A, Howard P, Volpato G, Santoro RF. Natural remedies and nutraceuticals used in ethnoveterinary practices in Inland Southern Italy. Vet Res Comm. 2004;28:55-80.

7. Ali-Shtayeh MS, Jamous RM, Jamous RM. Traditional Arabic Palestinian ethnoveterinary practices in animal health care: a field survey in the West Bank (Palestine). J Ethnopharmacol. 2016;182:35-49. 
8. Baharvand-Ahmadi B, Asadi-Samani M. A mini-review on the most important effective medicinal plants to treat hypertension in ethnobotanical evidence of Iran. J Nephropharmacol. 2017;6(1):3-8.

9. Akerreta S, Calvo MI, Cavero RY. Ethnoveterinary knowledge in Navarra (Iberian Peninsula). J Ethnopharmacol. 2010;130(2):369-78.

10. Benarba B, Belabid L, Righi K, Bekkar A, Elouissi M, Khaldi A, Hamimed A Ethnobotanical study of medicinal plants used by traditional healers in Mascara (north west of Algeria). J Ethnopharmacol. 2015;175:626-37.

11. Barkaoui M, Katiri A, Boubaker H, Msanda F. Ethnobotanical survey of medicinal plants used in the traditional treatment of diabetes in Chtouka Ait Baha and Tiznit (western anti-atlas), Morocco. J Ethnopharmacol. 2017; 198:338-50.

12. Di Sanzo P, De Martino L, Mancini E, De Feo V. Medicinal and useful plants in the tradition of Rotonda, Pollino National Park, southern Italy. J Ethnobiol Ethnomed. 2013;9(1):19.

13. Piluzza G, Virdis S, Serralutzu F, Bullitta S. Uses of plants, animal and mineral substances in Mediterranean ethno-veterinary practices for the care of small ruminants. J Ethnopharmacol. 2015;168:87-99.

14. Bullitta S, Piluzza G, Viegi L. Plant resources used for traditional ethnoveterinary phytoterapy in Sardinia (Italy). Genet Resour Crop Evol. 2007:54:1447-64.

15. Sindhu ZUD, Ullah S, Abbas RZ, lqbal Z, Hameed M. Inventory of ethnoveterinary practices used for the control of parasitic infections in district Jhang, Pakistan. Int J Agr Biol. 2012;14:922-8.

16. Yadav M, Rajput DS, Mishra P. Ethno-veterinary practices among tribes of Banswara District of Rajasthan. Indian Res J Ext Educ. 2016;15:87-90.

17. Kujawska M, Klepacki P, Łuczaj Ł. Fischer's plants in folk beliefs and customs: a previously unknown contribution to the ethnobotany of the polishLithuanian-Belarusian borderland. J Ethnobiol Ethnomed. 2017;13(1):20.

18. Martínez GJ, Luján MC. Medicinal plants used for traditional veterinary in the Sierras de Córdoba (Argentina): an ethnobotanical comparison with human medicinal uses. J Ethnobiol Ethnomed. 2011;7(1):23.

19. Council Regulation (EC) no. 834/2007 on Organic Production and Labelling of Organic Products. http://eur-lex.europa.eu/LexUriServ/LexUriServ.do?uri= OJ:L:2007:189:0001:0023:EN:PDF. Council Regulation (EC) no. 889/2008 on laying down detailed rules for the implementation of Council Regulation (EC) no. 834/2007. http://eur-lex.europa.eu/LexUriServ/LexUriServ.do?uri=OJ: L:2008:250:0001:0084:en:PDF. Accessed 17 July 2018.

20. Boukraa L, Benbarek $H$, Benhanifia M. Herbal medicines for animal health in the Middle East and North Africa (MENA) regions. In: Katerere DR, Luseba D, editors. Ethnoveterinary botanical medicine. Herbal medicines for animal health. Boca Raton, London, New York: CRC Press, Taylor \& Francis Group; 2010. p. 303-20

21. Lev E. Traditional healing with animals (zoo-therapy): medieval to present day Levantine practice. J Ethnopharmacol. 2003;85:107-18.

22. Quave CL, Pieroni A. Mediterranean zootherapy: a historical to modern perspective. In: RRN A, Rosa IC, editors. Animals in traditional folk medicine: implications for conservation. Berlin Heidelberg: Springer-Verlag; 2013.

23. Lawal OA, Banjo AD. Survey for the usage of arthropods in traditional medicine in southwestern Nigeria. J Entomol. 2007:4(2):104-12.

24. Alves RRN, Barbosa JA, Santos SL, Souto W, Barboza RR. Animal-based remedies as complementary medicines in the semi-arid region of northeastern Brazil. Evid Based Complement Alternat Med. 2011; https://doi. org/10.1093/ecam/nep134.

25. Martínez GJ. Use of fauna in the traditional medicine of native Toba (Qom) from the argentine Gran Chaco region: an ethno-zoological and conservationist approach. Ethnobiol Conservat. 2013;2:2-26.

26. Alonso-Castro AJ. Use of medicinal fauna in Mexican traditional medicine. J Ethnopharmacol. 2014;152:53-70.

27. Dossey AT. Insects and their chemical weaponry: new potential for drug discovery. Nat Prod Rep. 2010;27(12):1737-57.

28. Alves RRN, Rosa IL. Why study the use of animal products in traditional medicines? J Ethnobiol Ethnomed. 2005;1:5.

29. González JA, Amich F, Postigo-Mota S, Vallejo JR. Therapeutic and prophylactic uses of invertebrates in contemporary Spanish ethnoveterinary medicine. J Ethnobiol Ethnomed. 2016;12:36

30. Menale B, De Castro O, Cascone C, Muoio R. Ethnobotanical investigation on medicinal plants in the Vesuvio National Park (Campania, southern Italy). J Ethnopharmacol. 2016;192:320-49.

31. Wilkens B. La fauna sarda durante l'olocene: le conoscenze attuali. Int J Archeol. 2004;:1:181-97.
32. Mascheroni E. Zootecnia speciale. Equini. Torino: UTET; 1929.

33. Gratani L. Cavalli di Sardegna. Regione Autonoma della Sardegna, Assessorato Agricoltura e Riforma Agro-pastorale, Istituto Incremento Ippico della Sardegna. Sassari: Chiarella; 1984.

34. Viegi L, Bioli A, Vangelisti R, Cela Renzoni G. Prima indagine sulle piante utilizzate in medicina veterinaria popolare in alcune localita` dell'alta Val di Cecina. Atti Soc Tosc Sci Nat Mem Ser B. 1999;106:1-10.

35. Pignatti S. Flora d'Italia, vol. 1-3. Bologna: Edagricole; 1982.

36. Conti F, Abbate G, Alessandrini A, Blasi C. An annotated checklist of the Italian vascular flora. Roma: Palombi Editori; 2005.

37. Angiosperm Phylogeny Group. An update of the angiosperm phylogeny group classification for the orders and families of flowering plants: APG IV. Bot J Linn Soc. 2016;181:1-20.

38. Tardío J, Pardo-de-Santayana M. Cultural importance indices: a comparative analysis based on the useful wild plants of Southern Cantabria (Northern Spain). Econ Bot. 2008;62:24-39.

39. Pardo-de-Santayana M. Las plantas en la cultura tradicional de la antigua Merindad de Campoo. Ph.D. dissertation, Departamento de Biología, Facultad de Ciencias, Universidad Autónoma de Madrid, Spain. 2003.

40. Fois $P$, Mura L, Bullitta S. Plant genetic resources protection in the Mediterranean basin: the case of Sardinian forage species. Cah Options Méditerranéennes. 2000;45:109-12.

41. Bullitta S. Legal protection of local genetic resources and regulations for germplasm collection activities for scientific, economic and commercial purposes. In: Swiecicki W, Naganowska B, Wolko B, editors. Broad variation and precise characterization-limitation for the future. Eucarpia section genetic resources. Poznan: Prodruk; 2001. p. 15-8. ISBN 83-88518-47-X.

42. Voultsiadou E. Therapeutic properties and uses of marine invertebrates in the ancient Greek world and early Byzantium. J Ethnopharmacol. 2010;130: 237-47.

43. Ahmad TB, Liu L, Kotiw M, Benkendorff K. Review of anti-inflammatory, immune-modulatory and wound healing properties of molluscs. J Ethnopharmacol. 2017; https://doi.org/10.1016/j.jep.2017.08.008.

44. Meyer-Rochow VB. Therapeutic arthropods and other, largely terrestrial, folkmedicinally important invertebrates: a comparative survey and review. J Ethnobiol Ethnomed. 2017:13:9.

45. Quave $\mathrm{CL}$, Pieroni A, Bennet CB. Dermatological remedies in the traditional pharmacopoeia of vulture-alto Bradano, inland southern Italy. J Ethnobiol Ethnomed. 2008;4:5. https://doi.org/10.1186/1746-4269-4-5.

46. Confessor MV, Mendonça LE, Mourão JS, Alves RR. Animals to heal animals: ethnoveterinary practices in semiarid region, northeastern Brazil. J Ethnobiol Ethnomed. 2009:5(1):37.

47. Alves RRN, Alves HN. The faunal drugstore: animal-based remedies used in traditional medicines in Latin America. J Ethnobiol Ethnomed. 2011;7:9.

48. Volpato G, Kourková P, Zelený V. Healing war wounds and perfuming exile: the use of vegetal, animal, and mineral products for perfumes, cosmetics, and skin healing among Sahrawi refugees of Western Sahara. J Ethnobiol Ethnomed. 2012;8:49.

49. Jarald E, Edwin S, Tiwari V, Garg R, Toppo E. Antioxidant and antimicrobial activities of cow urine. Glob J Pharmacol. 2008;2(2):20-2.

50. Tulobaev AZ, Aldaiarov N, Jumakanova Z, Niiazbekova Z. Information on traditional veterinary knowledge of Kyrgyz people. Manas journal of agriculture and veterinary life. Science. 2016;6(2):29-35

51. Yadav ML, Rajput DS. Ethno-veterinary practices by tribals of Banswara district of Rajasthan. Indian J Nat Prod Res. 2015;6:237-40.

52. Maraver F, Fernández-Torán MÁ, Corvillo I, Morer C, Váquez I, Aguilera L, Armijo F. Pelotherapy, a review. Med Nat. 2015;9(1):38-46.

53. Volpato G, Saleh SML, Nardo A. Ethnoveterinary of Sahrawi pastoralists of Western Sahara: camel diseases and remedies. J Ethnobiol Ethnomed. 2015; 11(1):54.

54. Pieroni A, Nedelcheva A, Hajdari A, Mustafa B, Scaltriti B, Cianfaglione K, Quave CL. Local knowledge on plants and domestic remedies in the mountain villages of Peshkopia (eastern Albania). J Mt Sci. 2014;11(1): 180-93.

55. Ghazanfar SA. Wasm: a traditional method of healing by cauterization. J Ethnopharmacol. 1995:47:125-8.

56. Viegi L, Pieroni P, Guarrera PM, Vangelisti R. A review of plants used in folk veterinary medicine in Italy as basis for a databank. J Etnopharmacol. 2003: 89:221-44.

57. Atzei AD. Le piante nella tradizione popolare della Sardegna. Sassari: C. Delfino; 2003. 
58. González JA, García-Barriuso M, Amich F. Ethnoveterinary medicine in the Arribes del Duero, western Spain. Vet Res Commun. 2011;35(5):283-310.

59. Bonet MA, Vallès J. Ethnobotany of Montseny biosphere reserve (Catalonia, Iberian Peninsula): plants used in veterinary medicine. J Ethnopharmacol. 2007;110:130-47.

60. Cornara L, La Rocca A, Terrizzano L, Dente F, Mariotti MG. Ethnobotanical and phytomedical knowledge in the north-western Ligurian alps. J Ethnopharmacol. 2014;155:463-84.

61. Blanco E, Macía MJ, Morales R. Medicinal and veterinary plants of El Caurel (Galicia, Northwest Spain). J Ethnopharmacol. 1999;65:113-24.

62. Guarrera PM, Lucchese F, Medori S. Ethnophytotherapeutical research in the high Molise region (central-southern Italy). J Ethnobiol Ethnomed. 2008;4:7.

63. Goraya K, lqbal Z, Sajid MS, Muhammad G, ul Ain Q, Saleem M. Diversity of flora used for the cure of equine diseases in selected peri-urban areas of Punjab, Pakistan. J Ethnobiol Ethnomed. 2013;9(1):70

64. Bahmani M, Eftekhari Z. An ethnoveterinary study of medicinal plants in treatment of diseases and syndromes of herd dog in southern regions of Ilam province, Iran. Comp Clin Pathol. 2013;22:403-7.

65. Adhikary SP. Indigenous knowledge on animal care practices in Surada block of Ganjam District, Odisha. Eur J Environ Health Ecol. 2014;1 (1):1-6.

66. Lim TK. Camellia japonica. In: Edible medicinal and non-medicinal plants. Dordrecht: Springer; 2014. Print ISBN 978-94-017-8747-5.

Ready to submit your research? Choose BMC and benefit from:

- fast, convenient online submission

- thorough peer review by experienced researchers in your field

- rapid publication on acceptance

- support for research data, including large and complex data types

- gold Open Access which fosters wider collaboration and increased citations

- maximum visibility for your research: over $100 \mathrm{M}$ website views per year

At BMC, research is always in progress.

Learn more biomedcentral.com/submissions 